\title{
EL FACTOR RELIGIOSO EN EL CONFLICTO DE LAS COMUNIDADES DE CASTILLA (1520-1521). EL PAPEL DEL CLERO*
}

\author{
POR \\ Máximo Diago Hernando \\ Instituto de Historia. CSIC. Madrid
}

\section{RESUMEN}

Se analiza el conflicto de las Comunidades de Castilla en el contexto de los movimientos sociales con componente religioso que tuvieron lugar en Europa a fines del siglo XV y durante las primeras décadas del siglo XVI. Se trata de determinar el papel que en dicho conflicto desempeñó el factor religioso, prestando atención a diversas cuestiones como el papel político de las cofradías, la difusión de las profecías milenaristas o la utilización de la predicación como medio de propaganda política. Y a continuación se llama la atención sobre la participación en el conflicto de los miembros del clero, valorando el papel que desempeñaron en las instituciones comuneras, y el perfil social de los que militaron en el bando rebelde.

PAlABRAS ClAVE: Castilla,. Revuelta de las Comunidades, Conflictos sociales, Clero, Siglo XVI.

\section{ABSTRACT}

The conflict of the "Comunidades» of Castile is analyzed in the context of the social movements, with a religious component, that took place in Europe at the end of the fifteenth century and during the first decades of the sixteenth century. It is tried to determine the role played in that conflict by the religious

\footnotetext{
* Trabajo realizado en el marco del proyecto de investigación «El discurso político-religioso en la sociedad castellana. Elaboración y difusión». BHA2001-1029. El autor es miembro también del Grupo de Investigación validado por la Universidad Complutense $\mathrm{n}^{\circ} .930369$, «Sociedad, poder y cultura en la Corona de Castilla. Siglos XIII al XVI».
} 
factor, paying attention to several questions, namely: the political role of the religious confraternities, the spread of millenaristic prophecies, or the use of preaching as an instrument of political propaganda. And, next, attention is paid to the participation in the conflict of the clerics. It is valued the role that they played in the rebel institutions, and the social profile of the clerics that joined the rebels is finally analyzed.

KEY WORDS: Castile, Revolt of the «Comunidades», Social conflicts, Clergy, Sixteenth century.

Recibido/Received 09-10-2006

Aceptado/Accepted 13-11-2006

El FACTOR RELIGIOSO EN LOS CONFLICTOS POLÍTICOS Y SOCIALES EN LA EUROPA DEL TRÁNSITO dE LA EdAd MEdia A La Moderna

Las últimas décadas del siglo XV y las primeras del siglo XVI constituyeron un período de profundas transformaciones en las estructuras sociopolíticas y económicas del mundo europeo occidental, que generaron un clima de inestabilidad muy propicio para el estallido de conflictos políticos y sociales. Y, en efecto, se trató de un período particularmente conflictivo, durante el que se desencadenaron en ámbitos muy diversos del continente rebeliones contra la autoridad de gran calado, que han llegado a ser calificadas por algunos autores, no sin cierta exageración, como auténticas revoluciones, por considerar que buscaban la implantación de un orden social y político radicalmente nuevo.

Muchas de estas rebeliones tuvieron en común el hecho de que en ellas jugó un papel central el factor religioso, y contaron con la activa participación en el debate político de los miembros del estamento clerical. Pero, en claro contraste con lo ocurrido en fases más recientes de la historia europea, en que los miembros de este estamento apoyaron mayoritariamente los movimientos políticos de carácter más decididamente conservador, en el tránsito del período medieval al moderno por el contrario fueron muchos los que adoptaron posturas políticas de radical oposición al statu quo. Y así lo han resaltado algunos historiadores como Mario Miegge, para quien representa un hecho relevante el que a comienzos de la Edad Moderna algunas voces «autorizadas y proféticas» de la Iglesia occidental no se alineasen en la alianza de larga duración entre trono y altar, y se esforzasen por legitimar con argumentos religiosos los ideales de los regímenes republicanos, pues tales fenómenos no habrían sido frecuentes en la historia del cristianismo ${ }^{1}$.

\footnotetext{
${ }^{1}$ Mario MiegGe, «Dirigenti religiosi nelle città libere (1494-1548). Introduzione», en Girolamo Savonarola da Ferrara all'Europa, Florencia, Sismel-Edizioni del Galluzzo, 2001, p. 305.
}

Hispania Sacra, LIX

119, enero-junio 2007, 85-140, ISSN: 0018-215-X 
En la sociedad europea de comienzos de la Edad Moderna la religión seguía desempeñando un papel central, pues, como nos recuerda el profesor Mulett, conservaba su carácter de fuerza de masas, popular, que proporcionaba el principal mecanismo de defensa frente al miedo a la muerte que continuaba prevaleciendo en la masa de la población. Los europeos del siglo XVI, según este autor, todavía buscaban en la religión las respuestas a los problemas materiales y sociales que se les planteaban, en detrimento de las explicaciones racionalistas a las que tendemos a recurrir de forma prioritaria en nuestro mundo actual. Y por ello la religión continuaba siendo entonces esencialmente social e instrumental ${ }^{2}$.

En este contexto resulta por lo tanto perfectamente explicable que los movimientos políticos y sociales que en este período se desencadenaron en el continente continuasen estando fuertemente impregnados de argumentos de carácter religioso. Así se ha destacado muy en particular por algunos investigadores en el caso de la llamada guerra de los campesinos que estalló en Alemania en el año 1525, en pleno proceso de efervescencia del movimiento de reforma de la Iglesia puesto en marcha por Lutero en 1517. En concreto el profesor Blickle ha llamado la atención sobre el hecho de que los célebres Doce Artículos en que se recogieron las reivindicaciones de los rebeldes campesinos alemanes, constituían a la vez un programa de reforma y un manifiesto político, en que se apelaba al Evangelio como principio constituyente, y que perseguía el objetivo de organizar al mundo conforme al mensaje y exigencias de la Biblia ${ }^{3}$. Y, antes que en Alemania, también en Hungría, en la revuelta campesina que estalló en el año 1514, jugó un importante papel el factor religioso, potenciado por el papel que en su preparación desempeñaron los predicadores franciscanos, algunos de los cuales llegaron a convertirse después en líderes de los ejércitos campesinos ${ }^{4}$. Pero se ha de tener en cuenta, no obstante, que, como nos recuerda Freedman, la inspiración religiosa de los campesinos húngaros era hondamente tradicional, pues la idea de cruzada, que desde hacía siglos venía perdiendo fuerza en Europa, constituyó la principal expresión ideológica de su movimiento, que aspiraba a acabar con los privilegios de la nobleza húngara 5 .

La enorme relevancia que en el tránsito del mundo medieval al moderno tuvo la llamada guerra de los campesinos del año 1525, no nos debe hacer perder de vista, sin embargo, el hecho de que en este período fue sobre todo en las ciudades donde mayor desarrollo alcanzaron los movimientos reformistas, o incluso revolucionarios, en los que de forma prácticamente generalizada se conti-

2 Michael Mullett, La cultura popular en la Baja Edad Media, Barcelona, Crítica 1990.

3 Peter Blickle, Die Revolution von 1525, Múnich-Viena, Oldenbourg Verlag 1975, pp. 21-7.

4 Vid. Jenö SZÜCS, «Die oppositionelle Strömung der Franziskaner im Hintergrund des Bauernkrieges und der Reformation in Ungarn», Études historiques hongroises, vol. 2 (Budapest, 1985), pp. 483-512.

5 Paul FREEDMAN «La resistencia campesina y la historiografía de la Europa medieval», Edad Media. Revista de Historia, 3 (2000), p. 34. 
nuó dando una perfecta simbiosis entre teología y política. Así lo ha destacado el profesor Mario Miegge, para quien fueron las ciudades libres de Europa Central, todavía no integradas en los nacientes estados monárquicos centralizados, los principales escenarios de este original proceso en el que tuvieron una intensa participación los miembros del estamento clerical ${ }^{6}$. Un importante precedente de este tipo de movimientos fue sentado en Florencia entre los años 1494 y 1498, cuando el predicador dominico Girolamo Savonarola tuvo en sus manos las riendas del gobierno de la ciudad 7 . Pero fue en las décadas que siguieron a la ruptura de Lutero con Roma cuando mayor número de ciudades, localizadas en su mayor parte en el territorio centroeuropeo, en los actuales estados de Suiza, Francia, Alemania, Bélgica y Holanda, fueron escenario de intensos procesos de cambio político y social que tuvieron un fuerte componente religioso, pues estuvieron inextricablemente vinculados con el proceso de implantación de la reforma en las estructuras eclesiásticas de dichas ciudades. Esta reforma, en efecto, no se circunscribió al mero ámbito organizativo de la Iglesia, sino que tuvo una importante vertiente teológica, que, además, se proyectó sobre la realidad social y política, que experimentaron como consecuencia una intensa transformación.

Peter Blickle reconstruye en los siguientes términos los procesos de protesta social que se desencadenaron en las ciudades centroeuropeas en el marco de la implantación en ellas de la reforma protestante. En una primera fase comenzarían los predicadores a difundir críticas contra el Papa, los monasterios y el clero, para pasar luego a cuestionar la postura de la Iglesia en ciertos puntos, y finalmente entrar de lleno en la esfera social. En una segunda fase, se iniciaría el proceso de debilitamiento de la posición de los órganos de gobierno local de las ciudades (Rat), que verían declinar su autoridad, y cuestionada su legitimidad, hasta el punto de llegar a constituirse en oposición a ellos comités comunales en pro de la Reforma. Y, en una tercera fase, cristalizaría ya la protesta en revuelta, exigiéndose la deposición de los oficiales de gobierno que permaneciesen fieles a la antigua fe, o la introducción de otros cambios de carácter constitucional que, no obstante, rara vez llegaron a consolidarse ${ }^{8}$. En conjunto, según Blickle, todos estos procesos de protesta social que se desencadenaron en las

\footnotetext{
${ }^{6}$ Mario MiegGe, op. cit.p. 305.

${ }^{7}$ Entre la abundante bibliografía existente sobre esta temática cabe destacar Donald WeINSTEIN, Savonarola e Firenze. Profezia e patriotismo nel Rinascimento, Bolonia, 1976 (Traducción italiana del original inglés). Entre los recientes balances historiográficos puede mencionarse el de Gian Carlo GARFAGNINI, «Savonarola e Firenze: Spunti per un bilancio storiografico», Girolamo Savonarola da Ferrara all'Europa, Florencia, Sismel-Edizioni del Galluzzo 2001, pp. 313-324.

8 Peter BLICKLE, «Social Protest and reformation Theology», Religion, Politics and Social Protest. Three Studies on Early Modern Germany, Londres, 1984, p. 7. De este mismo autor interesa también su obra Reformation und kommunaler Geist: Die Antwort der Theologen auf den Verfassungswandel im Spätmittelalter, Múnich, 1996.
}

Hispania Sacra, LIX

119, enero-junio 2007, 85-140, ISSN: 0018-215-X 
ciudades centroeuropeas al hilo de la implantación de la reforma protestante durante la primera mitad del siglo XVI, persiguieron, entre sus principales objetivos, garantizar la autonomía del individuo, establecer a la comunidad como principio fundamental de la organización socio-política, y el «bien común» como principio de legitimación ética de la existencia humana. Y, por tanto, en este contexto la protesta social habría tratado de que en la esfera secular se llevasen a la práctica los mismos principios e ideales que la teología reformada se esforzaba por implantar en las esferas eclesiástica y espiritual ${ }^{9}$.

De ahí que en todos estos procesos de cambio social y político que se desencadenaron de forma preferente en las llamadas «ciudades libres» de Europa central en la primera mitad del siglo XVI, el factor religioso alcanzase un inusual protagonismo, que tuvo su traducción en la frecuente asunción del liderazgo en la vida política local por clérigos y teólogos. Estudios dedicados a figuras como las de Zwinglio ${ }^{10}$ y Bullinger ${ }^{11}$ en Zurich, Calvino en Ginebra ${ }^{12}$, Bucer en Estrasburgo ${ }^{13}$ o Rothmann en Münster ${ }^{14}$, por citar sólo las más relevantes, han realizado una importante contribución a la reconstrucción del perfil de estos «líderes religiosos», que sin duda constituyen uno de los elementos más originales del paisaje sociopolítico europeo del tránsito del mundo medieval al moderno, por su doble compromiso con la reforma en el ámbito teológico-eclesiástico y en el político-social. En prácticamente ningún otro período de la historia consiguieron los teólogos que se les reconociese tan importante liderazgo en la vida política, pues, además, como nos recuerda Miegge, se trató de un liderazgo con ambiciones transformadoras, que contrasta con el papel que en otras fases de la historia europea desempeñó el clero, de orientación eminentemente conservadora.

Constatado este hecho, conviene preguntarse, no obstante, qué ocurrió en este mismo período en otros ámbitos de la Europa occidental donde el mayor desarrollo de los aparatos de gobierno de los estados monárquicos había impuesto severas restricciones al régimen de autogobierno de las ciudades, y éstas habían dejado de representar un marco propicio para el lanzamiento de ambi-

\footnotetext{
${ }^{9}$ Peter BLICKLE, «Social Protest...», pp. 16-17.

10 Vid. Emidio CAMPI, «Religione e politica a Zurigo: Il ruolo di Zwingli», Girolamo Savonarola da Ferrara..., pp. 421-436.

11 Vid. Fritz BüSSER, «L'azione di Bullinger nella città di Zurigo», Girolamo Savonarola da Ferrara..., pp. 437-450.

12 Vid. Francis Higman, «La république de Genève: Le rôle de Jean Calvin », Girolamo Savonarola da Ferrara..., pp. 465-476.

13 Vid. Bernard VogLER, «Le magistrat de Strasbourg et les réformateurs (1520-1549) », Girolamo Savonarola da Ferrara..., pp. 451-6.

14 Vid. Valerio MARChETTI, «Bernhard Rothmann e la città di Münster», Girolamo Savonarola da Ferrara..., pp. 457-64.
} 
ciosos proyectos de reforma de las estructuras sociopolíticas vigentes, porque por encima de ellas existían unas estructuras «estatales» sobre las que era preciso actuar para que resultase factible cualquier tipo de cambio.

Entre estos ámbitos hemos de destacar a la Corona de Castilla, donde desde mediados del siglo XIII los aparatos de gobierno central de la monarquía fueron acaparando progresivamente mayores parcelas de poder frente a las instancias locales, y más en particular frente a los grupos gobernantes de las ciudades del realengo. Como consecuencia de este proceso, a fines del siglo XV y comienzos del XVI, el modelo de gobierno vigente en las ciudades castellanas estaba muy alejado del que por las mismas fechas disfrutaban gran número de ciudades centroeuropeas e italianas, integradas en su mayoría en el Imperio, a las que los historiadores han calificado como «libres», en atención al elevado grado de autonomía del que disfrutaban frente a las instancias políticas superiores. Y a pesar de ello, sin embargo, en este convulso período de transición del mundo medieval al moderno, también muchas ciudades de la Corona de Castilla fueron escenario de intensos conflictos políticos, que culminaron en la rebelión que un gran número de ellas iniciaron contra su joven rey Carlos I en la primavera del año 1520 .

La revuelta de las Comunidades fue un movimiento de notable envergadura, sin paralelos en la historia de Castilla ni en el período medieval ni en el moderno, y que por ello ha ejercido un gran atractivo sobre los historiadores ya desde el propio siglo XVI, que han ofrecido interpretaciones de signo muy dispar sobre su significado y sobre las razones que explican su estallido y su fracaso. Por regla general, sin embargo, este conflicto ha sido analizado de forma casi exclusiva desde una perspectiva exclusivamente castellana, sin ponerlo en relación con otros procesos ocurridos en el ámbito europeo occidental en el mismo período.

Desde la perspectiva de la historia comparada ofrece, sin embargo, notable interés determinar en qué medida este proceso de rebelión de las ciudades castellanas participó de esa tendencia general de imbricación de religión y política que se dio en numerosos ámbitos de la Europa ultrapirenica en las primeras décadas del siglo XVI, muy en particular en las ciudades «libres». De hecho, se tiene desde hace tiempo constancia de que durante los años 1520 y 1521 los miembros del clero tuvieron una participación en la vida política de las ciudades en particular, y del reino en su conjunto, bastante más intensa de lo que hasta entonces había sido habitual, al menos por lo que se refiere a amplios sectores del estamento no integrados en el ámbito cortesano, pues los clérigos con influencia en la Corte sí venían desempeñando un activo papel político desde hacía muchos siglos. Esta constatación podría llevarnos en principio a aventurar la hipótesis de que también en la Castilla de principios del siglo XVI floreció la figura del dirigente religioso que tuvo una de sus primeras manifestaciones más acabadas en el dominico Savonarola, en la Florencia de la última década del si- 
glo XV. Pero antes de llegar a tan apresurada conclusión, convendría detenerse en analizar cuál fue el programa que los clérigos que intervinieron en política en Castilla durante los meses de la revuelta comunera trataron de llevar a la práctica, y si estuvo tan imbuido de elementos religiosos como el de sus colegas de las ciudades del otro lado de los Pirineos.

Todo esto es lo que nos hemos propuesto llevar a cabo en el presente trabajo, que responde al doble objetivo de analizar desde la perspectiva de la historia comparada los conflictos sociales que tuvieron por escenario el continente europeo en el período de tránsito del mundo medieval al moderno, y de valorar la incidencia que el factor religioso continuaba teniendo en la sociedad europea de comienzos de la Edad Moderna.

El FACTOR RELIGIOSO EN EL CONFLICTO DE LAS COMUNIDADES DE CASTILla. CONSIDERACIONES GENERALES DESDE EL PUNTO DE VISTA COMPARATIVO

La Corona de Castilla no fue durante el período medieval un territorio particularmente fértil para el desarrollo de movimientos sociales fuertemente impregnados de connotaciones religiosas del tipo de los que tuvieron lugar más allá de los Pirineos, protagonizados por grupos condenados por las autoridades eclesiásticas como herejes, del tipo de los valdenses o los cátaros ${ }^{15}$. A fines del Medievo sí se dieron algunos fenómenos de este tipo, pero de forma muy aislada, como nos testimonia el célebre caso de los herejes de Durango, en el señorío de Vizcaya ${ }^{16}$.

A principios del siglo XVI, cuando arrancó en el Occidente cristiano un importante proceso de renovación teológica, con enormes consecuencias políticas y sociales, no resultaba apenas posible en territorio castellano, por tanto, enlazar con una consistente tradición de contestación social de inspiración religiosa, como la había en otras tierras al otro lado de los Pirineos, y que en el siglo XV había experimentado una fuerte revitalización en territorios como el de Bohemia. Quizás por este motivo, al proceder al análisis interpretativo del movimiento de las Comunidades que tuvo por escenario la Corona de Castilla en el momento en que en otros ámbitos se iniciaba el proceso de la Reforma protestante, los investigadores no han destacado por regla general la importancia del factor religioso en el mismo.

\footnotetext{
${ }^{15}$ Algunas referencias a las escasas repercusiones que estos movimientos heréticos «de masas» tuvieron en los reinos de Castilla y León, Francisco Javier FERNÁNDEZ CONDE, La religiosidad medieval en España. Plena Edad Media (siglos XI-XIII), Gijón, Ediciones Trea 2005.

16 Vid. José GoÑI GaZTAmbIDE, «Los herejes de Durango. Nuevas aportaciones (1442)», Hispania Sacra, 55 (1975), pp. 225-238.
} 
Sí han sido varios, sin embargo, los autores que han llamado la atención sobre la enorme difusión que alcanzaron durante los meses de la revuelta las profecías de tipo milenarista. La fuente más pródiga en informaciones sobre estas profecías es la relación manuscrita atribuida a Gonzalo de Ayora conservada en la Biblioteca Nacional de Madrid. Y, por su parte, uno de los principales cronistas del reinado de Carlos I, Prudencio de Sandoval, hizo alusión al fenómeno en los siguientes términos:

«Inventaron algunos demonios no sé qué profecías, que decían eran de San Isidro, arzobispo de Sevilla; otras de fray Juan de Rocacelsa, y de un Merlin y otros dotores, y de San Juan Damasceno; llantos o plantos que lloró San Isidro sobre España. Y en todas ellas tantos anuncios malos de calamidades y destrucción de España, que atemorizaban las gentes y andaban pasmados... Particularmente creían los ignorantes en una que decía que había de reinar en España uno que se llamaría Carlos, y que había de destruir el reino y asolar las ciudades. Pero que un infante de Portugal le había de vencer y echar del reino, y que el infante había de reinar en toda España»17.

Entre los estudiosos de la revuelta comunera de los siglos XIX y XX no se concedió, sin embargo, gran importancia a este factor como determinante del estallido o de la radicalización de la misma, con la única excepción significativa de Ramón Alba, que publicó una obra monográfica en 1975 en la que destacó la intensa actividad desarrollada por algunos predicadores que adoptaron una ideología milenaria para las masas, llegando a identificar a Carlos con el Anticristo ${ }^{18}$, y defendió la tesis de que a los capitanes Juan Padilla y Juan Bravo, y al obispo Acuña, principales dirigentes del movimiento, se les atribuyó por la masa de la población un carácter mesiánico, llegando a gozar de un fervor popular sólo comparable al que en otros tiempos habían gozado santos y profetas $^{19}$.

Las tesis de Ramón Alba no tuvieron en su momento, sin embargo, mucha repercusión, y sólo en fechas muy recientes otros autores las han retomado, formulándolas incluso en una versión mucho más explícita, influenciados probablemente por otros historiadores que han destacado el papel de las profecías milenaristas en el movimiento agermanado en el reino de Valencia. Es el caso de Jaime Contreras, quien recientemente ha defendido la tesis de que «el movimiento comunero tuvo desde sus primeras manifestaciones una vertiente religiosa que le otorgó cierto carácter mesiánico y milenarista» 20 .

\footnotetext{
${ }_{17}$ Prudencio de SAndoval, Historia de la Vida y Hechos del Emperador Carlos V, Madrid, BAE 1955 , t. I, pp. 259-260.

${ }^{18}$ Ramón AlBA, Acerca de algunas particularidades de las Comunidades de Castilla tal vez relacionadas con el supuesto acaecer terreno del Milenio Igualitario, Madrid, 1975, p. 111.

${ }^{19}$ Ibidem, p. 124.

${ }^{20}$ Jaime Contreras Contreras, «Profetismo y apocalipsismo: Conflicto ideológico y tensión social en las Comunidades de Castilla», en Fernando MarTínez GIL (Coord.) En torno a las Comunidad-
} 
Ciertamente durante los siglos XV y XVI mesianismo y milenarismo seguían ejerciendo una enorme fascinación en toda Europa sobre los sectores populares $^{21}$. Esto explica que la difusión de profecías de carácter milenarista continuase desempeñando un importante papel en muchos de los movimientos políticos y sociales que se desencadenaron en este período en el continente. Así, por poner un significativo ejemplo, cabe destacar el papel clave que este tipo de profecías desempeñaron en las predicaciones de Girolamo Savonarola en Florencia entre los años 1494 y 1498, período durante el que este fraile dominico consiguió imponer su dominio sobre la ciudad que desde hacía mucho tiempo venía gobernando de facto la familia de los Medicis, introduciendo drásticos cambios en las costumbres y la propia concepción de las relaciones sociales y políticas, que pasaron a quedar plenamente determinadas por ideales religiosos. Savonarola ha sido calificado por el profesor Mullett como un visionario y profeta joaquinita, y sus sermones encerraron todo un sistema profético, caracterizado por la alternancia dramática de crisis y esperanza 22.

Por lo que respecta a la Corona a Castilla los testimonios documentales no dejan lugar a dudas sobre la notable profusión con que circularon allí a fines del siglo XV y comienzos del siglo XVI las profecías milenaristas. Pero resulta algo más cuestionable que las mismas desempeñasen un papel de primera fila como factor desencadenante de la revuelta de las Comunidades, o de su radicalización en las fases álgidas del conflicto. Muy probablemente los frailes, y en menor medida también algunos clérigos laicos, incluirían en sus sermones referencias de carácter milenarista del tipo de las que utilizó con profusión Savonarola en los suyos en Florencia. Pero ésta era una forma de proceder habitual, que contaba con importantes precedentes en el reino de Castilla, como, por ejemplo, los sentados por el dominico valenciano San Vicente Ferrer en las campañas de predicación que realizó en este reino a principios del siglo $\mathrm{XV}$, durante la minoría de Juan II en las que manejó con profusión el tópico de la venida del Anticristo ${ }^{23}$. Y no disponemos de testimonios que nos permitan asegurar que esta temática se erigiese en argumento central de sus discursos, en un contexto dominado por las preocupaciones de tipo religioso, pues el objetivo que persiguieron estos predicadores durante los meses de la revuelta no fue tanto el de conseguir una reforma en profundidad de las costumbres del pueblo, a la manera como lo pretendió Savonarola, sino más bien recabar el apoyo de éste

es de Castilla. Actas del Congreso Internacional «Poder, conflicto y revuelta en la España de Carlos I», Ediciones de la Universidad de Castilla-La Mancha, Cuenca, 2002, p. 525.

${ }^{21}$ Michael Mullett, La cultura popular en la Baja Edad Media, Crítica, Barcelona, 1990, p. 175.

${ }^{22}$ Michael Mullett, op. cit. pp. 162 y ss. Sobre el carácter apocalíptico-milenarista de las predicaciones de Savonarola vid. también Donald WEINSTEIN, op . cit.

${ }^{23}$ Vid. Pedro M. CÁtedra, Sermón, sociedad y literatura en la Edad Media. San Vicente Ferrer en Castilla (1411-1412), Junta de Castilla y León, Valladolid, 1994. 
para sacar adelante una serie de reformas del régimen de gobierno de orientación eminentemente secular.

Entendemos, por tanto, que durante las comunidades el profetismo de sesgo milenarista pudo ser utilizado como instrumento de propaganda política, y pudo desempeñar hasta cierto punto una importante función movilizadora de los sectores populares. Pero no representó un argumento central del movimiento, que tenía una orientación eminentemente secular, sin las connotaciones de proceso de purificación espiritual que quiso imprimir Savonarola al movimiento que él puso en marcha en Florencia de la última década del siglo XV, y que también podemos encontrar planamente desarrolladas en las revueltas sociales asociadas a la introducción de la reforma en muchas ciudades centroeuropeas en las primeras décadas del siglo XVI. Quizás no le falte razón al profesor Contreras cuando sostiene que en las palabras de muchos ideólogos comuneros, en particular franciscanos y dominicos, se percibe un cierto sentir profético según el cual parece que aquellos frailes creían que el conflicto que animaban no sólo era justo sino también santo ${ }^{24}$. Pero creemos que dichos ideólogos se limitaron a proporcionar argumentos de carácter espiritual que contribuyesen a reforzar la legitimidad de un movimiento que tenía una orientación decididamente secular, pues no se marcaba como objetivo imponer una radical reforma de las costumbres, ni de la organización eclesiástica, que hiciese posible la construcción de una sociedad santa y pura.

Sin duda las principales destinatarias del mensaje profético y milenarista fueron las masas populares, más inclinadas hacia la radicalización, y la difusión del mismo entre éstas es probable que contribuyese a despertar y exacerbar los ánimos antinobiliarios e igualitarios. Pero, en honor a la verdad, hemos de reconocer con Fernando Martínez Gil que disponemos de muy pocos datos que nos permitan conocer la lógica de los comportamientos y verdaderas motivaciones de los comuneros de baja extracción y de sus líderes, y del entramado mental y religioso que servía de base a sus acciones ${ }^{25}$. Por ello hablar de las masas comuneras de las ciudades castellanas como «pueblo de Dios en marcha», según nos propone Jaime Contreras, nos parece que no responde plenamente a la realidad que nos permite entrever la documentación conservada. Por el contrario, no tenemos noticia de que en tierras castellanas llegasen a plantearse entre los años 1520 y 1522 fenómenos equiparables al de la aparición del Encubert, personaje mesiánico que contribuyó a mantener vivo el fuego de la rebelión ager-

\footnotetext{
24 Jaime CONTRERAS CONTRERAS, art. cit. p. 525.

25 Fernando MARTínez GIL, «Furia popular. La participación de las multitudes urbanas en las Comunidades de Castilla», en Fernando MARTínez GiL (Coord.) En torno a las Comunidades de Castilla. Actas del Congreso Internacional «Poder, conflicto y revuelta en la España de Carlos I», Edicones de la Universidad de Castilla-La Mancha, Cuenca, 2002, p. 315.
}

Hispania Sacra, LIX

119, enero-junio 2007, 85-140, ISSN: 0018-215-X 
manada en su fase final en los reductos de Alcira y Xátiva. Por ello nos sentimos inclinados a pensar que el factor milenarista desempeñó un papel bastante más importante en la revuelta agermanada del reino de Valencia que en la comunera del reino de Castilla, en consonancia con el mayor protagonismo que los argumentos de tipo religioso alcanzaron en el discurso de los rebeldes valencianos ${ }^{26}$.

Al margen de la difusión alcanzada por las profecías milenaristas, algunas otras circunstancias ponen de manifiesto que durante la revuelta de las Comunidades el factor religioso estuvo muy presente, como no podía ser de otro modo en una sociedad que todavía no había iniciado apenas el proceso de su secularización, que en la actualidad podemos considerar plenamente concluido. Así, en primer lugar, se ha de destacar que una ceremonia fundamental en la práctica totalidad de las ciudades y villas que se sumaron a la rebelión fue la de la prestación del juramento a la Comunidad, llevada a cabo en catedrales e iglesias, siguiendo el ejemplo sentado por la ciudad de Toledo, donde dicha ceremonia se celebró con gran solemnidad en el día de la fiesta del Corpus Christi ${ }^{27}$.

El juramento tenía asignado un papel central en la cultura política de la época, aunque en la Corona de Castilla puede decirse que experimentó una indiscutible revalorización durante el conflicto comunero, al exigirse su prestación a todos los vecinos, como forma de garantizar su compromiso de apoyo a las nuevas instituciones de gobierno, en contraste con lo que había sido hasta entonces la norma dominante, que sólo exigía la prestación de juramento a los oficiales de gobierno ${ }^{28}$. Pero conviene recalcar que, aunque se trató de una práctica con implicaciones preferentemente políticas, en todo momento se puso especial cuidado en revestirla con un ropaje religioso, poniéndola en conexión con el símbolo y la imagen de la cruz, de la forma más explícita posible. Y de este modo se procedió tanto en el bando comunero como en el realista. Así, por lo que toca a este último, sirva recordar la actuación del corregidor de Córdoba, Diego de Osorio, quien, habiendo obligado a un fraile a predicar en la plaza para mover al pueblo a mantenerse fiel a la causa del rey, después de finalizado el sermón «sacó una cruz dorada y hiço que todos alçasen las manos y jurasen, y juraron de todos sienpre estar en servicio de su majestad» 29 . Y, por su parte,

26 Vid. Eulalia Durán. «Aspectos milenaristas en las germanías valencianas», El Contemporani: Revista d'Història, 5 (1995), pp. 21-29. Y «El mil.lenarisme al servei del poder i del contrapoder», en Ernest Belenguer Cebriá (Ed.), De la Unión de Coronas al Imperio de Carlos V, Madrid, 2001, vol. II, pp. 293-308.

27 Vid. Fernando Martínez GIL, La ciudad inquieta..., p. 152.

28 Vid. Máximo Diago Hernando, «Transformaciones en las instituciones...», pp. 651-3.

${ }^{29}$ Manuel Danvila Collado, Historia crítica y documentada de las Comunidades de Castilla, en Memorial Histórico Español, vols. XXXV-XL, Madrid, 1897-1900. Las referencias a esta obra las realizaremos indicando en número romano el número de orden que ocupa el volumen citado entre los seis 
un curioso testimonio de esta práctica tomado del campo comunero nos lo proporciona la denuncia presentada contra un clérigo de Cazorla, acusado de haber andado con una cruz juramentando a los vecinos de la villa para que estuviesen en Comunidad y la favoreciesen ${ }^{30}$.

La cruz fue, por lo demás, un elemento que se utilizó con profusión durante los meses de la revuelta por los rebeldes comuneros en sus acciones políticas callejeras, como elemento legitimador, con el que se trataría de hacer pública ostentación del convencimiento de estar llevando a cabo una acción justa y santa. Pero conviene precisar que los testimonios más explícitos de esta práctica que hasta el momento hemos logrado reunir proceden del reino de Murcia, precisamente el territorio de la Corona de Castilla donde los argumentos de tipo religioso mayor espacio ocuparon en el discurso de los rebeldes comuneros, como consecuencia de la influencia que allí ejerció el movimiento agermanado. Así, por poner un ejemplo paradigmático, cabe recordar que en la fiesta de la Ascensión del año 1520 los miembros de la recién fundada cofradía de San José, en la que se agrupaban los comuneros murcianos, salieron en gran número del claustro de la catedral en dirección a la cárcel, para sacar de ella a varios presos, llevando consigo una cruz grande, además de tambores y banderas, que conferían a la marcha un complejo carácter de desfile militar y a la vez procesional-religioso.

La frecuencia con que se dieron este tipo de fenómenos cabe explicarla como consecuencia de la forma inextricable en que piedad y violencia coexistían en la vida cotidiana de los castellanos de esta época. Los documentos de las dos primeras décadas del siglo XVI nos demuestran, en efecto, que lo sagrado era un elemento omnipresente en la vida de las gentes de las ciudades de la Corona de Castilla, poco dadas a desplazarlo al ámbito de la vida privada conforme al modelo hoy dominante en las sociedades occidentales. Pero esta omnipresencia conllevaba que estas mismas gentes manifestasen pocos reparos a la hora de transgredir las fronteras que separaban lo sagrado de lo profano, llevando la violencia al corazón mismo de los espacios sacros. La noticias sobre homicidios y otras acciones violentas en el interior de las iglesias abundan sobre manera en la documentación castellana de esta época. Y los implicados en este tipo de acciones no fueron ni mucho menos exclusivamente laicos, sino que los testimonios incriminatorios contra clérigos son también abundantísimos, a pesar de que las restricciones que el derecho canónico imponía a estos últimos en el ejercicio de la violencia eran mucho más severas que en el caso de los laicos.

volúmenes que abarca en la edición del Memorial Histórico Español, teniendo en cuenta que el vol I corresponde al XXXV de la colección, y así sucesivamente. Aquí V, pp. 473-8. Fragmentos del proceso de residencia a D. Diego de Osorio, corregidor que fue de Córdoba.

${ }^{30}$ DanVILA, V, pp. 48-9.

Hispania Sacra, LIX

119, enero-junio 2007, 85-140, ISSN: 0018-215-X 
En cualquier caso, aunque es cierto que con frecuencia el sentimiento de veneración por lo sagrado, y las prácticas piadosas asociadas a él, que tan enorme arraigo mantenían en la sociedad castellana de comienzos del siglo XVI, no bastaron para frenar la propensión a la violencia tan arraigada en esa misma sociedad, hubo otras ocasiones en que sí lo lograron. Y como testimonio sirva recordar un caso ocurrido en Plasencia durante los meses de la revuelta comunera. Habían salido, en efecto, a la plaza y calles de esta ciudad gran número de vecinos, armados de arneses, coseletes, picas y otras armas, que se pusieron a pelear unos contra otros, por diferencias que mantenían en torno a la designación de la persona que había de hacerse cargo del control de la fortaleza realenga de Plasencia. Pero, cuando varios clérigos y frailes salieron de la catedral en solemne procesión con el Santísimo Sacramento y la cruz, consiguieron de inmediato detener los combates, posibilitando así que a continuación los oficiales de la justicia impusiesen una tregua de un año de duración a todos los miembros de los bandos que se disputaban el ejercicio del poder en aquellos momentos en Plasencia ${ }^{31}$.

Para terminar con esta serie de consideraciones sobre el papel del factor religioso en el conflicto de las Comunidades, interesa recordar que el valor simbólico de los números alcanzó notable relevancia en algunos casos concretos, que, no obstante, de nuevo podemos constatar que se concentran en el ámbito del reino de Murcia, confirmando así que allí, en directo paralelo con lo que ocurrió en el reino de Valencia, el factor religioso incidió en muy mayor medida en el devenir del conflicto comunero que en el resto del territorio castellano. En efecto, sabemos que tanto en la ciudad de Murcia, como en otros núcleos urbanos de segundo rango del reino, tales como Lorca o Cartagena, el principal cambio institucional que trajo consigo el triunfo de la Comunidad fue la introducción de la figura de los síndicos, cuyo numero se fijó en doce, «a nombre de los doce apóstoles», a los cuales, al menos en Murcia y Cartagena, se añadió un «principal y cabeza, a reverencia de Nuestro Señor Jesucristo»32.

${ }^{31}$ DANVILA, II, pp. 141-5.

32 Sobre Murcia Vid. AGS, RGS, VI-1520. Comisión al contino García de Montalvo. Se denuncia que los sublevados murcianos «tenían intención de hacer 12 síndicos a nombre de los 12 apóstoles, y un principal y cabeza a reverencia de Nuestro Señor Jesucristo, para que los susodichos tuviesen sus capitanías y juntasen su gente a repique de campana». Sobre Lorca Vid. AGS, RGS, VII-1520. Provisión al licenciado Sancho Díaz Leguízamo, alcalde de Casa y Corte. Se denuncia que el lunes 25 de junio se juntaron muchos vecinos de Lorca «a manera de la germanía de Aragón», como se levantaron los vecinos de Murcia, e hicieron cierta hermandad y liga, y «tienen señaladas doce personas, que llaman síndicos». Sobre Cartagena AGS, RGS, VII-1521. Provisión al corregidor de Murcia y Cartagena, a petición de Diego Ros, vecino de Cartagena, como procurador de los regidores y jurados de la ciudad. Aquí se hace constar que «tomaron por fuerza la gobernación Martín Alonso, capitán de la germanía y comunidad, y 13 síndicos que se hicieron, los cuales se apoderaron de la ciudad y gobernación de ella, y de la cámara del cabildo y ayuntamiento». 
UTILIZACIÓN CON FINES POLÍTICOS DE LAS ASOCIACIONAES DE CARÁCTER RELIGIOSO DURANTE LA REVUELTA COMUNERA

Un aspecto de la revuelta comunera que nos pone de manifiesto la profunda interpenetración que todavía se daba en la Castilla de comienzos del siglo XVI entre lo religioso, lo político y lo social es el de la utilización durante la misma de las cofradías como plataformas para el despliegue de actividades de naturaleza puramente política. Ciertamente dicha utilización sólo puede documentarse con un mínimo detalle en un reducido número de lugares, pero no hay que excluir que alcanzase mucha más difusión, dado que las fuentes documentales conservadas y analizadas hasta ahora por los investigadores sólo proporcionan una imagen muy fragmentaria de la compleja realidad histórica de este período.

Algunos de los ejemplos más significativos y mejor documentados de esta práctica los encontramos precisamente en el reino de Murcia, que, una vez más, presenta evidentes paralelismos a este respecto con el vecino reino de Valencia, que ejerció una indudable influencia sobre él en este particular contexto histórico. Como ya hemos adelantado, fue en el reino de Murcia donde, a juzgar por las fuentes documentales conservadas, el movimiento de las Comunidades presentó un más perceptible componente religioso, que ofrece evidentes semejanzas con el que inspiró al movimiento agermanado. Y en su capital encontramos el más completo testimonio de la utilización de una cofradía con fines políticos de cuantos tenemos documentados en la Corona de Castilla durante los años 1520 y 1521. En efecto, sabemos que en abril de 1520 se fundó en esta ciudad una cofradía bajo la advocación de San José, que desde el primer momento comenzó a contar entre sus principales actividades las de carácter abiertamente político. Entraron a formar parte de ella todos los vecinos que simpatizaban con la causa de las comunidades, aunque en una variante muy influida por la germanía valenciana, los cuales la utilizaron como principal marco asociativo para llevar adelante su proyecto político de radical modificación del régimen de gobierno de la ciudad ${ }^{33}$.

Como consecuencia, la celebración de las principales festividades religiosas se convirtió en ocasión para la realización de actividades políticas de marcado carácter reivindicativo, que en más de una ocasión desembocaron en desórdenes y graves alteraciones del orden público, que desencadenaron importantes cambios en el escenario político local. Así en concreto, el día de la fiesta de la Ascensión del año 1520 se reunieron en el claustro de la catedral, mientras se decía misa, más de trescientos hombres, miembros de esta cofradía, que salieron de allí con repique de campanas, porque así estaba concertado, se armaron,

33 Tomamos la información de AGS, RGS, VI-1520. Comisión al contino García de Montalvo. Luego se expidió una carta de comisión de idéntico tenor dirigida al licenciado Leguízamo, que fue quien actuó como juez pesquisidor, pues no se tiene constancia de que García de Montalvo lo hiciese.

Hispania Sacra, LIX

119, enero-junio 2007, 85-140, ISSN: 0018-215-X 
$\mathrm{y}$ «con atambor y tres banderas» marcharon desfilando «en ordenanza» hasta las puertas de la cárcel, que trataron de quebrantar por la fuerza para liberar a varios presos que en ella estaban, todo ello portando consigo una cruz grande, y proclamando en voz alta la consigna de «Viva el rey y la justicia pública».

La estrecha imbricación de elementos políticos y religiosos en estas actuaciones de la cofradía resulta a todas luces evidente, y se fue intensificando con el paso del tiempo. El objetivo principal que se perseguía con las mismas era de naturaleza política, ya que buscaban el desplazamiento de los regidores y caballeros de los órganos de gobierno de la ciudad, y la implantación de un nuevo régimen que propiciase la participación en dichos órganos de los sectores populares pecheros. Pero la persecución de estos objetivos de carácter abiertamente secular fue revestida con un ropaje netamente religioso, sin que resulte fácil dilucidar si esto obedeció a mera estrategia propagandística o fue consecuencia de una sincera y espontánea conexión del movimiento con las convicciones religiosas más profundas de la masa de la población.

La cofradía de San José de Murcia se llegó a convertir, en cualquier caso, en un mecanismo movilizador de masas de enorme efectividad, que, según algunas estimaciones, fue capaz de reunir en sus alardes públicos a más de seiscientos hombres. La forma adoptada para su organización interna presentaba por otra parte un evidente perfil militar, pues contemplaba la existencia de capitanes que convocaban a sus gentes a repique de campana, y organizaban desfiles por las calles de la ciudad, con enorme despliegue de tambores, banderas y estandartes. En concreto tenemos noticia de la celebración de multitudinarios desfiles en la festividad de la Ascensión y durante la Pascua de Pentecostés. Pero además se denunció que durante los mismos los cofrades actuaban de forma intimitadoria contra aquellos sectores de la población que no se habían incorporado a la cofradía, y muy en particular contra los vecinos ricos.

Los paralelismos en la forma de actuar de la cofradía de San José de Murcia en la primavera del año 1520 y de las cofradías de los oficios de Valencia por estas mismas fechas son, por otra parte, bastante evidentes. En esta última ciudad, en efecto, según nos recuerda Rafael Narbona, durante el año 1520 las fiestas patronales de dichas cofradías de oficio se convirtieron en ocasión para el alarde militar, que desplazó a un lugar secundario su carácter mutual, religioso y comensal tradicional. Y este proceso llegó a su culminación el día de carnaval de ese mismo año, cuando entre 7.000 y 8.000 hombres agrupados bajo 40 banderas desfilaron, en toda una demostración de fuerza, ante el cardenal Adriano de Utrecht, procurador de Carlos I desplazado a Valencia para jurar los fueros y privilegios de ciudad y reino de Valencia en su nombre ${ }^{34}$.

\footnotetext{
34 Rafael Narbona Vizcaíno, «La ciudad de Valencia y las Germanías», en Ernest Belenguer CeBRIÀ (Coord.), De la unión de coronas al Imperio de Carlos V, vol. II, Madrid, 2001, p. 330.
} 
Fuera del reino de Murcia, no obstante, también puede constatarse la utilización de las cofradías como plataformas de acción política en otros ámbitos de la Corona de Castilla durante los meses de la revuelta comunera. Un ejemplo muy interesante lo encontramos en la villa de Ágreda, donde se fundaron dos cofradías en el transcurso del año 1520, bajo las advocaciones de Corpus Christi y Ánimas del Purgatorio, que desde el primer momento adoptaron un sesgo decididamente político.

La primera en crearse fue la de Corpus Christi, de la que entraron a formar parte en un primer momento en torno a cuarenta personas, que tenían en común su pertenencia al estamento pechero y, al parecer, ciertas simpatías con la causa de las comunidades. La segunda cofradía, bajo la advocación de las Ánimas del Purgatorio, fue instituida poco tiempo después por los hidalgos, en virtud de una reacción de carácter defensivo, al considerar que la fundación de la del Corpus Christi representaba una amenaza para sus intereses, y precisaban de un adecuado marco asociativo para su defensa, y garantizar el apoyo a la causa realista en la villa. Ambas cofradías se crearon, por consiguiente, con una evidente intencionalidad política, pero no por ello dejaron de desempeñar las actividades de carácter religioso propias de este tipo de asociaciones, de forma que, por ejemplo, nos consta que la de las Ánimas celebraba todas las semanas una misa.

Según la versión de los hechos proporcionada por los representantes de la cofradía de las Ánimas del Purgatorio ${ }^{35}$, los cofrades del Corpus Christi habían realizado asambleas ilícitas «so color que se juntaban a la dicha cofradía», de las que se habían derivado acciones políticas en apoyo del movimiento comunero, entre las que destacó la de arrebatar las varas de la justicia al corregidor y sus oficiales. Ante esta perspectiva de que se implantase la Comunidad en la villa de Ágreda, como consecuencia de las actuaciones de los pecheros agrupados en la cofradía del Corpus Christi, los hidalgos habían decidido instituir la cofradía de las Ánimas del Purgatorio, a la que también se incorporaron algunos pecheros. Y por esta vía consiguieron poner freno a los proyectos de los pecheros procomuneros, quienes, siempre según la versión de los hidalgos, tras haberse percatado de que no podían llevar a cabo su propósito, decidieron formar un frente común con ellos, comprometiéndose a continuación todos mediante juramento a favorecer la justicia «y las cosas tocantes al servicio del rey». Como consecuencia la villa de Ágreda estuvo durante un tiempo pacífica «sin haber memoria de comunidad». Por este motivo varios hidalgos que eran señores de ganados trashumantes no vieron inconveniente en marchar a Extremadura para

35 Esta versión la reconstruimos a partir de la información contenida en AGS, RGS, X-1521. Comisión al corregidor de Ágreda. Algunos detalles complementarios en RGS, VIII-1521. Comisión al corregidor de Soria

Hispania Sacra, LIX

119, enero-junio 2007, 85-140, ISSN: 0018-215-X 
atender sus explotaciones ganaderas, pero en su ausencia muchos pecheros, «como vieron que Juan de Padilla andaba por estos reinos con gente armada, volvieron a tener opinión de Comunidad so color de cofradía». Este nuevo giro procomunero de los pecheros se tradujo en graves desórdenes, con ataques armados a varias casas e incluso a una iglesia, que desembocaron al parecer en la expulsión del corregidor y de su alcalde, y en su sustitución por alcaldes nombrados por la sociedad política local.

No podemos entrar a determinar hasta qué punto esta versión de los hechos es plenamente acorde con la realidad, y los pecheros de Ágreda, agrupados en la cofradía del Corpus Christi, dieron su apoyo a la causa de las comunidades, mientras que sus rivales de la cofradía de las Ánimas lo hicieron a la causa realista. Lo cierto, en cualquier caso, es que el conflicto planteado entre los miembros de ambas cofradías no se vio en lo más mínimo apaciguado tras la derrota de los ejércitos comuneros en los campos de Villalar, sino que, por el contrario, después de esta batalla, que precipitó el fin de la rebelión en la submeseta norte, se siguió arrastrando durante varios meses con notable virulencia, a pesar de los numerosos intentos que hubo por aplacarlo. Cabe deducir, por tanto, que dicho conflicto respondía a causas diferentes de las que desencadenaron la revuelta de las Comunidades, y que el apoyo de los miembros de la cofradía del Corpus Christi a la causa comunera no debió ser tan explícito como sostuvieron sus rivales de la cofradía de las Ánimas, pues de lo contrario la represión ejercida sobre ellos por los gobernadores tras Villalar hubiese sido mucho más intensa. Por el contrario sabemos que no lo fue, y buena prueba de ello es que la cofradía del Corpus Christi continuó desplegando una importante actividad durante la primavera del año 1521. En concreto se ha de destacar que, cuando se aproximaba la fecha de la fiesta del Corpus, sus miembros manifestaron su intención de salir públicamente en procesión. Por temor a que de ello pudieran resultar desórdenes, el corregidor lo prohibió, pero ante esta prohibición los cofrades reaccionaron de manera violenta, marchando a las casas del concejo para sacar algunas de las armas que allí se depositaban. Y, amparados en la protección que estas armas les proporcionaban, «comieron su cofradía sin que la justicia de la iglesia se lo pudiese resistir», por lo que el corregidor, ante tal muestra de desacato, decidió abrir información para enviarla al Consejo Real ${ }^{36}$.

Este incidente nos viene a poner de manifiesto una vez más hasta qué punto en Ágreda en estos meses las actividades de índole religiosa y las de índole política se confundieron de forma inextricable, conformando dos caras de una misma realidad, gracias a la utilización de las cofradías como instrumentos de acción política. Por ello, para restaurar el orden en la villa, hubo que actuar sobre las propias cofradías, y en un primer momento de trató de hacerlo por la

${ }^{36}$ AGS, RGS, Burgos 28-VIII-1521. 
vía del compromiso, mediante la elección de jueces árbitros, que fueron el regidor de Soria, Juan Morales, y el fiscal de la Chancillería de Valladolid, el doctor Fernán Gómez de Agreda. Ambos dictaron una sentencia arbitral que fue presentada para su confirmación ante el Consejo Real en el transcurso del mes de agosto de $1521^{37}$. En ella se garantizó la continuidad de las dos cofradías en el estado en el que entonces se encontraban, es decir, sin que se pudiese incorporar ningún nuevo miembro a ellas, pero al mismo tiempo se impusieron fuertes restricciones a su derecho de reunión, para evitar que continuasen siendo utilizadas como plataformas para la acción política. En concreto los jueces dispusieron que los «ayuntamientos de cofrades» quedasen suspendidos por un año, plazo que, llegado el momento, podría prorrogarse si ellos así lo estimaban oportuno. Durante este tiempo las cofradías quedaban autorizadas a continuar celebrando las misas que tuviesen previstas según sus constituciones, pero no podrían asistir a dichas celebraciones litúrgicas los cofrades, para evitar así que estuviesen reunidos. Y, por supuesto, también quedó terminantemente prohibido que las personas que favorecían a una u otra cofradía pudiesen andar juntos o «en gavillas» por la villa para evitar que de ello se pudiesen derivar «escándalos». A cambio se dispuso también en la sentencia que todas las acciones emprendidas por el corregidor contra los cofrades quedasen anuladas.

A pesar de haber sido confirmada por el Consejo Real, la sentencia arbitral del regidor Juan Morales y el doctor de Ágreda, no debió ser observada por las partes implicadas, puesto que poco tiempo después los gobernadores ordenaron al corregidor de Ágreda, por provisión fechada en Burgos el 28 de agosto de 1521 , que procediese a la disolución de las dos cofradías, argumentando que los cofrades, a pesar de que se les había prohibido que se reuniesen, habían continuado haciéndolo. Al parecer, los hidalgos miembros de la cofradía de las Ánimas mostraron mayor disposición a acatar esta orden de disolución, pues, según hicieron saber en la Corte en octubre de 1521, habían dejado de reunirse tras serles notificada la real provisión, pero, por el contrario, los cofrades de Corpus Christi habían apelado de la misma, y continuaban reuniéndose, y prestándose mutuamente apoyo para actuar contra sus enemigos, en ocasiones de forma muy violenta ${ }^{38}$. Y de hecho nos consta que al menos seis miembros de la cofradía del Corpus Christi fueron condenados por el corregidor de Ágreda a que se presentasen presos en la cárcel de la Corte, mientras que al resto de cofrades a los que se encontró culpables de desobediencia se les condenó a pena de destie-

37 AGS, RGS, VIII-1521. Confirmación de la sentencia arbitral, que se inserta, a petición de Juan de Sayas y García Navarro, procuradores de las cofradías del Corpus Christi (pecheros) y de las Ánimas del Purgatorio (hidalgos).

38 AGS, RGS, X-1521. Provisión dirigida a los mayordomos de las cofradías de Ágreda, ordenándoles que se cumpla lo dispuesto en la provisión de Burgos, 28-VIII-1521, que se inserta.

Hispania Sacra, LIX

119, enero-junio 2007, 85-140, ISSN: 0018-215-X 
rro fuera de la villa durante el tiempo que el Consejo Real tardase en resolver el litigio ${ }^{39}$.

La utilización de las cofradías como marco para la realización de actividades políticas no fue por estas fechas un fenómeno exclusivo de Ágreda, aunque para otros lugares no disponemos de información documental tan abundante que nos lo permita conocer con el suficiente detalle. Sí contamos, no obstante, con algunas someras referencias que dan fe del desarrollo de fenómenos relativamente parecidos en lugares próximos, como, por ejemplo, Calahorra. Allí, en efecto, Antón Gualite denunció en nombre del concejo a fines del año 1522 que los hidalgos de la ciudad habían realizado cierto ayuntamiento ilícito «a voz de cofradía», sin contar para ello con facultad real o licencia de prelado. Y por ello solicitó la prohibición de tal cofradía, argumentando que constituía de hecho una «liga y monipodio», que realizaba sus reuniones en una «casa privada», y que además buscaba perjudicar al conjunto de vecinos de la ciudad, al aliarse con el cabildo de la catedral en el pleito que éste mantenía con el concejo calagurritano ${ }^{40}$.

Por lo demás, otros testimonios documentales nos demuestran que en la época el potencial subversivo de las cofradías era percibido de forma generalizada por los gobernantes, que por este motivo en los momentos inmediatamente posteriores al aplastamiento de la revuelta comunera en Villalar decidieron en más de un caso suspender temporalmente el derecho de reunión a sus miembros. Así procedió en concreto el corregidor de León, Bernardino de Ledesma, quien nada más tomar posesión de su cargo a mediados de mayo de 1521, rogó a los miembros de las cofradías que realizaban asambleas en la ciudad que dejasen de reunirse, a no ser que previamente le informasen de su intención de hacerlo $^{41}$.

Y también disponemos de algunos testimonios aislados que prueban que, durante los meses de la revuelta comunera, la celebración por determinadas cofradías de una festividad religiosa fue ocasión para el despliegue de acciones

39 AGS, RGS, X-1521. Provisión a petición de Martín Guerra, Diego Polo, Diego Guerra, Martín Polo, Hernán Celorrio y Miguel Quiles, vecinos de Ágreda y cofrades del Corpus Christi, que habían solicitado autorización para poder abandonar la Corte, a donde se habían presentado cumpliendo órdenes del corregidor de Ágreda. Habían alegado que vivían de su trabajo, y en frontera del reino de Navarra, donde podía haber necesidad de ellos para cosas cumplideras al servicio del rey.

40 AGS, RGS, X-1522. Provisión dirigida al corregidor de Calahorra. Para encuadrar esta denuncia en su contexto histórico interesan los siguientes trabajos. Máximo Diago HeRnANDo, «El concejo de Calahorra durante el reinado de los Reyes Católicos: Aspectos de su organización institucional», Berceo,144 (2003), pp. 93-123. Y «Clérigos y laicos en la lucha por el poder en la ciudad de Calahorra a fines de la Edad Media: Los conflictos entre los oficiales del concejo y el cabildo de la catedral», Berceo, 148 (2005), pp. 93-124.

${ }^{41}$ AGS, Cámara-Memoriales, 140-81. Memorial de Bernardino de Ledesma, fechado en Léon, 20V-1521. 
políticas, que no necesariamente derivaron siempre en graves alteraciones del orden público, sino que en ocasiones se mantuvieron en el terreno estrictamente propagandístico. Así ocurrió, por ejemplo en Toledo el 23 de enero de 1521, festividad de San Ildefonso, el patrono local, cuando la celebración por la cofradía de Nuestra Señora la Antigua de una misa en la catedral fue aprovechada para proporcionar al agustino procomunero Santamarina, calificado por sus enemigos como «revolvedor de pueblos», un marco privilegiado para el desempeño de su tarea propagandística a favor de la causa comunera, imponiéndole como predicador en contra de la opinión mayoritaria del cabildo catedralicio ${ }^{42}$.

LA PREDICACIÓN AL SERVICIO DE LA PROPAGANDA POLÍTICA DURANTE LA REVUELTA COMUNERA

La expansión de las Órdenes Mendicantes por todo el continente europeo durante los siglos bajomedievales propició un fuerte desarrollo de la práctica de la predicación, que llegó a adquirir en ocasiones la condición de auténtico espectáculo de masas, pues los predicadores, para ganarse el favor del público, llegaron a asumir el papel de auténticos actores, que realizaban todo tipo de gesticulaciones a fin de asegurar un mayor impacto a sus discursos, que solían tender hacia la grandilocuencia. Por supuesto, el objetivo principal de los sermones era entonces, como ahora, transmitir al pueblo la doctrina cristiana, a través de comentarios sobre las enseñanzas que se podían extraer de las Sagradas Escrituras. Pero, al mismo tiempo también, en determinados ámbitos, entre los que cabe destacar el de las ciudades italianas, en estos sermones se trató de abarcar todos los otros aspectos de la vida humana y de la tarea política, además del estrictamente religioso, pues el proyecto apostólico de los frailes mendicantes que los predicaban se dirigía tanto al individuo como a la sociedad, y no separaba por consiguiente al hombre privado del ciudadano ${ }^{43}$. Esta tendencia llegó a su culminación en la ciudad de Florencia en la última década del siglo XV, cuando el dominico Girolamo Savonarola encauzó decididamente su actividad como predicador hacia el terreno político, convirtiéndose en el principal agente promotor de un proyecto político que propiciaba el retorno a las virtudes florentinas tradicionales, el puritanismo cívico, la simplicidad y el gobierno popular, y buscaba la conversión de Florencia, bajo formas republicanas, en una ciudad santa ${ }^{44}$.

\footnotetext{
42 Vid. Fernando MarTínez GiL, op. cit., p. 326.

${ }^{43}$ André VAUCHEZ, «Gli Ordini mendicanti e le città nell’Italia dei comuni (XIII-XV secolo). Alcune riflessioni vent anni dopo», en Giorgio CHITTOLINI y Kaspar ELM (Eds.), Ordini religiosi e società politica in Italia e Germania nei secoli XIV e XV, Il Mulino, Bologna, 2001, p. 40.

44 Vid. Michael Mullett, op. cit. pp. 162-3. Una visión más centrada en los aspectos espirituales de la predicación de Savonarola, que recalca el tono amenazante de la misma, en Berndt HAMM, «Tra 
Esta decidida orientación política de la predicación no se dio de forma generalizada en toda la Europa bajomedieval, pues también algunos autores han llamado la atención sobre su ausencia en determinados ámbitos. Así, por poner un único ejemplo, cabe recordar que según Nicole Beriou la temática política apenas estuvo presente en las predicaciones que tuvieron por escenario París en el siglo XIII, salvando algunas breves alusiones al poder real, debido a que el objetivo principal que perseguían los predicadores era elevar el nivel moral y espiritual de los fieles, sin tener cuenta de la dimensión social de su existencia ${ }^{45}$.

Desde esta perspectiva la Corona de Castilla ofrece a fines del Medievo evidentes paralelismos con la situación de las ciudades italianas, pues fue muy habitual que los sermones predicados entonces en sus principales ciudades por los frailes de las Órdenes Mendicantes tuviesen un explícito contenido político. Un interesante ejemplo, aunque de fecha posterior a las que aquí estamos tomando en consideración, de cómo un sermón basado en el comentario de las Sagradas Escrituras podía adquirir un tinte decididamente político nos lo proporciona el que predicó en la catedral de Toledo el primer domingo después de la Ascensión del año 1524 el prior del convento de San Agustín de esa capital castellana. En efecto, al final de dicho sermón este fraile incluyó unas breves palabras de apoyo al corregidor Don Martín de Córdoba y de denuncia contra aquellos miembros de la sociedad política local que en aquellos momentos estaban exigiendo que se le sometiese a juicio de residencia. Para mostrar su desacuerdo con la actitud de estos últimos estableció un curioso paralelismo con lo que ocurrió cuando Jesucristo subió a los cielos, y los ángeles se espantaron de verle con llagas, para a continuación proclamar que no era buena gente la que por tales obras le había dado tal pago. Y de forma explícita hizo ver a continuación a los fieles que le escuchaban en la catedral que, del mismo modo que los hombres, y más en concreto los judíos, habían sido injustos con Jesucristo, los toledanos que entonces estaban reclamando el juicio de residencia para el corregidor saliente lo estaban siendo con éste, teniendo en cuenta que había impartido justicia y mantenido la cibdad en paz $^{46}$. Es decir, que este fraile agustino utilizó el púlpito de la catedral en un día de fiesta para transmitir un mensaje de claro contenido político, sirviéndose del establecimiento de símiles con la historia sagrada para causar un mayor impacto en su auditorio, y lograr que éste se mostrase más receptivo.

severità e misericordia. Tre tipi di prediche riformatrice nelle città prima della Riforma: SavonarolaGeiler-Staupitz», Girolamo Savonarola da Ferrara all'Europa, Sismel-Edizioni del Galluzzo, Florencia, 2001, pp. 347-381.

45 Vid. Nicole BÉRIOU, L'avènement des maîtres de la Parole. La prédication à Paris au XIIIe. siècle, París, 1998.

46 DANVILA, V, pp. 513-6. 
No resulta sorprendente, por tanto, que, tras escuchar este sermón, un importante sector de la sociedad política toledana protestase airadamente contra lo que consideró una intromisión escandalosa de un miembro del clero en la vida política local. Y, en respuesta a estas protestas, el juez de residencia que entonces estaba actuando en Toledo, el licenciado Briviesca, alcalde de Casa y Corte, se apresuró a solicitar al provincial de la Orden de San Agustín que impusiese algún castigo al fraile que había predicado el sermón, por su osadía, y al deán y canónigos de la catedral toledana que no le consistiesen en adelante volver a predicar en ella, y «estubiesen sobre abiso para no consentir que los predicadores se metiesen en estas cosas».

Lo cierto, no obstante, es que estas intromisiones de los predicadores en la controversia política de las ciudades castellanas habían venido siendo muy frecuentes en los años que precedieron al episodio que acabamos de analizar. De hecho, las predicaciones con fuerte contenido político se habían intensificado en Castilla a partir del momento de la llegada al reino del nuevo monarca, Carlos I, en 1517, cuando numerosos clérigos y, sobre todo, frailes se lanzaron a manifestar abiertamente en sus sermones opiniones hostiles al nuevo personal político que trajo éste consigo, en su mayor parte de origen flamenco, y a denunciar la forma en que dicho personal estaba conduciendo los asuntos públi$\cos ^{47}$. Y lo hicieron siguiendo el modelo de establecimiento de símiles y paralelismos con las Sagradas Escrituras al que nos acabamos de referir. Sirva como ilustración de esta práctica un breve repaso al contenido del sermón pronunciado en la iglesia de San Esteban de Valladolid por el franciscano fray Juan de San Vicente el día 26 de diciembre de 1518, festividad de San Esteban ${ }^{48}$. Remitiéndose a la historia de este santo que relatan los Hechos de los Apóstoles, estableció un paralelismo entre la situación en que se encontraba la comunidad cristiana de Jerusalén en tiempo de San Esteban, dividida entre griegos y hebreos que se disputaban su dirección, y la que entonces atravesaba el reino de Castilla, con los flamencos enfrentados a los castellanos. Y propuso imitar la sabiduría de los apóstoles, que, a fin de superar aquel estado de división, habían procedido a designar siete diáconos de buena reputación para que tomasen a su cargo la administración de la comunidad, invitando a los grandes a unirse a los representantes del pueblo para designar siete personas con reputación de sabios y honestos, que se encargasen de reorganizar la administración del reino y reformar los abusos. A esta propuesta le añadió, no obstante, un matiz de sesgo claramente ideológico, al excluir la posibilidad de que alguno de estos siete hombres sabios se pudiese designar entre los miembros de la alta nobleza caste-

${ }^{47}$ Joseph PÉREZ, «Moines frondeurs et sermons subversivs en Castille pendant le premier séjour de Charles Quint en Espagne», Bulletin Hispanique, LXVII, nums. 1-2 (1965), pp. 5-24.

48 Ibidem, p. 13.

Hispania Sacra, LIX

119, enero-junio 2007, 85-140, ISSN: 0018-215-X 
llana o entre los extranjeros que habían acudido en compañía del rey. Habían de reclutarse, sin embargo, según su punto de vista entre los «medianos» del reino, porque los grandes sólo actuaban movidos por sus pasiones e intereses particulares, y esto les llevaba a enfrentarse los unos con los otros, en lugar de trabajar juntos por el bien de todos ${ }^{49}$.

Algunos de los elementos principales de la ideología comunera, como es el sentimiento anti-flamenco y la orientación anti-nobiliaria, pueden detectarse ya, por tanto, en estado embrionario en este sermón predicado en Valladolid por fray Juan de San Vicente a fines de 1518, y los encontramos también más o menos desarrollados en otros varios sermones pronunciados por las mismas fechas en ésta y otras capitales castellanas ${ }^{50}$. La politización del contenido de los sermones fue, no obstante, intensificándose en los siguientes meses, hasta alcanzar el paroxismo tras el estallido de la revuelta comunera, cuando la predicación se consolidó como uno de los principales instrumentos de propaganda y adoctrinamiento político a disposición de las dos partes en conflicto.

Los púlpitos representaban entonces el cauce más eficaz para hacer llegar a los sectores populares las consignas políticas, por cuanto los predicadores gozaban de gran credibilidad entre dichos sectores, en su mayor parte analfabetos, y que por esta razón no resultaban accesibles a través de la palabra impresa. Y por ello, durante la guerra de las Comunidades, los de uno y otro bando, conscientes de la importancia de la propaganda como medio de lucha, trataron de ganarse para su causa a los predicadores, presionándoles para que orientasen al pueblo en el sentido por ellos propiciado. Así, por ejemplo, a Don Diego de Osorio, que fue corregidor de Córdoba durante los meses de la revuelta, se le atribuyó el haber desarrollado una intensa labor para persuadir a los predicadores de que predicasen «lo que convenía a servicio del rey y paz y sosiego destos reynos y para que fuesen castigados los que algunas cosas escandalosas predicavan», consciente de que los predicadores»podían hazer mucho provecho e daño para el sosiego de la dicha cibdad». Y, por este motivo habría obligado al prior de San Pablo de Córdoba, fray Gregorio, a salir a la plaza de la Corredera para predicar un sermón en presencia del pueblo «fecho a propósito de animar al pueblo para que estuviesen en servicio de su majestad» ${ }^{51}$.

\footnotetext{
${ }^{49}$ En concreto se le atribuía haber propuesto en su sermón «Que de los medianos del reyno y no de los Grandes se escogiesen personas que entendiesen en la governación del reyno, y que estos que avían de ser de los naturales del reyno y no estranjeros». Para descalificar a los grandes había dicho que «con sus pasiones y con sus yntereses particulares, el uno por que le vuelvan lo que tenía de Málaga y el otro por que le vuelvan otra cosa que quería, los unos a los otros se estorvavan e ladravan como perros».

${ }^{50}$ Da noticia de varios de ellos Joseph Pérez, Ibidem, pp. 16 y ss.

${ }^{51}$ Danvila, V, pp. 473-8. Fragmentos del proceso de residencia a D. Diego de Osorio, corregidor que fue de Córdoba.
} 
Mucho más activos que los predicadores ganados para la causa realista, estuvieron, sin embargo, los que optaron por apoyar la revuelta. Y así nos los confirman numerosos testimonios de la época, que concuerdan en atribuir a los predicadores, sobre todo a los precedentes del clero regular, una importante responsabilidad en el estallido de la rebelión. Así, en primer lugar, antes de que éste se desencadenase, ya algunos se mostraron alarmados por los efectos desestabilizadores que podrían tener los sermones que se estaban predicando en algunas ciudades. De ello da fe una carta autógrafa dirigida por Andrés de Haro al cardenal Adriano en la que, tras haberse referido a algunos predicadores que estaban dando sermones en Medina del Campo en contra de los flamencos y del rey, afirmaba que «nunca hubo revuelta ni escandalo en estos Reynos que no fuese el principio dello los predicadores, como agora lo comienzan a faser estos» ${ }^{52}$. Y, varios años después de aplastada la revuelta, fue el propio emperador el que reconoció en una carta dirigida al Papa que «los predicadores y frayles cabsaron en las alteraciones pasadas que ovo en los nuestros reynos de Castilla muy grandes daños con sus sermones y hablas y lo mismo hicieron muchos clerigos ricos de los cabildos de las cibdades y villas del reyno» ${ }^{53}$.

Conscientes de la importancia que para ganar apoyos para su causa tenía el disponer de buenos predicadores, los dirigentes comuneros se preocuparon por reclutar a los más prestigiosos, haciéndolos venir incluso de fuera de sus ciudades. Un elocuente testimonio en este sentido nos lo proporciona la acusación presentada después de Villalar contra el zamorano Juan de Porras, a quien se responsabilizó de haber trabajado para que viniesen frailes de fuera «que predicasen en favor de la comunidad en deservicio del rey nuestro señor», logrando por su «mano e industria» que acudiese a Zamora el guardián de Salamanca para predicar en desacatamiento y deservicio del rey ${ }^{54}$.

Las acusaciones contra frailes que predicaron a favor de las Comunidades durante los meses de la revuelta son muy numerosas. Por supuesto donde éstos desplegaron una más intensa actividad fue en aquéllas ciudades que de forma más decidida apoyaron la rebelión, como es el caso de Toledo, donde, según un testigo que declaró en el proceso contra Juan de Gaitán, en el tiempo en que la ciudad estuvo rebelada contra el rey «había pocos predicadores que predicasen verdad ${ }^{55}$. En Salamanca, sabemos que destacó un fraile por sus predicaciones

\footnotetext{
52 Danvila, II, pp. 776-7. Danvila propone fechar esta carta en Medina del Campo, 6-XII-1520. Pero por su contenido entendemos más bien que debería fecharse en 1519.

${ }^{53}$ Minuta de una carta del emperador, fechada en Génova, 30-VIII-1529, solitando un breve pontificio para poder castigar a los frailes y clérigos que predicasen contra el servicio y tranquilidad del Estado, en DANVILA, V, p. 642.

${ }^{54}$ DANVILA, IV, pp. 655-8.

55 Fernando MARTÍnEZ GIL, «Furia popular....», p. 324.
} 
«en deservicio de Dios, del rey y del reino», y por ello una de las primeras actuaciones del corregidor enviado por los gobernadores a la ciudad después de Villalar fue la de ordenar su detención, asegurándose de que permaneciese preso en la cárcel del maestrescuela, según comunicó satisfecho al cardenal Adriano por carta de 24 de junio de $1521^{56}$. Pero también tenemos noticia de las actuaciones de estos predicadores procomuneros en ciudades que permanecieron fieles al rey, como Córdoba, a donde acudió en los primeros días de marzo de 1521 el agustino fray Juan Bravo con la intención de «alborotar» al pueblo con sus sermones, e invitarle a que se rebelase contra el rey ${ }^{57}$. E incluso nos consta que algunos no cesaron en su empeño después de la derrota del ejército comunero en los campos de Villalar, pues, por ejemplo, en junio de 1521 el concejo de Toro denunció ante los gobernadores que el vicario de la ciudad, varios dominicos del monasterio de San Ildefonso, y otras personas eclesiásticas, «perseverando en sus errores y desatinadas intenciones», continuaban predican muchas cosas en deservicio del rey «y para provocar a las gentes a que tornasen a los dichos levantamientos y escándalos» ${ }^{58}$.

EL PAPEL DE LOS CLÉRIGOS EN LA ELABORACIÓN DEL PROGRAMA POLÍTICO COMUNERO

No son muchos los documentos disponibles para conocer en detalle el programa político de los comuneros, o sus fundamentos teóricos. La falta de documentos programáticos demuestra a nuestro entender que el de las Comunidades no fue un movimiento bien estructurado, con unos objetivos perfectamente definidos, al modo como nos lo han tratado de presentar algunos historiadores, sino que hubo mucho en él de improvisación. Y, en cualquier caso, la celeridad con que fue aplastado por las fuerzas realistas impidió que alcanzase el grado de madurez suficiente como para que sus ideólogos pudiesen llegar a definir ni siquiera un esbozo de «programa» propiamente dicho, si es que efectivamente era éste el objetivo que se perseguía.

En el movimiento comunero castellano no podemos encontrar nada equiparable a los Doce Artículos en que se condensó el programa de reforma de los campesinos alemanes del año 1525, que estaban fuertemente inspirados por el pensamiento teológico, dado que en ellos se apelaba al Evangelio como fundamental principio constituyente ${ }^{59}$. Las reivindicaciones comuneras se situaron en un nivel mucho más pragmático, y por ello en vano buscaremos en los docu-

\footnotetext{
56 DANVILA, IV, p. 237.

57 DANVILA, III, p. 543.

58 AGS, RGS, VI-1521.

59 Peter BliCKLE, Die Revolution..., pp. 21-7.
} 
mentos en que se plasmaron invocaciones a la Biblia, o a las obras de los teólogos universitarios.

Esta ausencia de referentes religiosos en los documentos programáticos comuneros resulta llamativa, teniendo en cuenta la notable participación que presumimos debieron tener en su elaboración numerosos miembros del estamento clerical, y en particular los procedentes de aquellos sectores de dicho estamento más inclinados hacia la reflexión teológica, como eran los frailes de las órdenes mendicantes, y, en menor medida, los miembros de los cabildos de las catedrales y colegiatas.

De hecho tenemos constancia de que algunos individuos próximos al movimiento comunero procedían de los medios universitarios, o al menos se encontraban en muy estrecho contacto con ellos. Es el caso, por ejemplo de Alonso de Castrillo, autor de una obra titulada Tratado de República y otras antigüedades, publicada en Burgos en 1521, el cual había sido discípulo del prestigioso teólogo Fernando de Roa, profesor de la universidad de Salamanca, en quien se inspiró en gran medida al redactar dicha obra, hasta el punto de seguirle de forma literal en algunos pasajes ${ }^{60}$. Otro ejemplo notable de comprometido comunero procedente de estos mismos medios universitarios nos lo proporciona el comendador Griego, Hernán Núñez de Toledo, pensador humanista con inclinaciones pro-erasmistas ${ }^{61}$, quien poseyó un ejemplar de la referida obra de Alonso de Castrillo, que actualmente se conserva en la Universidad de Salamanca, en los márgenes del cual escribió algunas anotaciones, alabando el criterio igualitario y democrático del catedrático salmantino ${ }^{62}$.

También muy vinculado con la universidad, en este caso con la de Valladolid, estuvo el fraile dominico Alonso de Bustillo, quien llegó a ser titular de una cátedra de teología en la misma, y por su intensa participación en la revuelta comunera fue uno de los exceptuados del perdón concedido por el rey a los rebeldes $^{63}$. Y, por poner un último ejemplo, cabe recordar que prestó un importante apoyo al movimiento comunero en Toledo el obispo de Utica, quien presidió la ceremonia de juramento de la Comunidad por los vecinos que tuvo lugar en

\footnotetext{
${ }^{60}$ Vid. Enrique Tierno Galván, «De las comunidades, o la historia como proceso», Boletín Informativo del Seminario de Derecho Político, Universidad de Salamanca, 16-19 (1957), pp. 147-8.

${ }^{61}$ Helen NADER, «The Greek Commander Hernán Núñez de Toledo, Spanish Humanist and Civic Leader», Renaissance Quaterly, 31 (1978), pp. 463-485. Y Juan Signes CodoÑER, Carmen CodoÑER Merino y Arantxa Domingo Malvadí, Biblioteca y epistolario de Hernán Núñez de Guzmán (El Pinciano). Una aproximación al humanismo español del siglo XVI, Madrid, CSIC, 2001. Destaca su orientación erasmista J.A. Maravall, Las Comunidades de Castilla, Alianza Universidad, Madrid, 1979, p. 194.

62 José Luis Castillo Vegas, Política y clases medias. El siglo XV y el maestro salmantino Fernando de Roa. Universidad, Valladolid, 1987, p. 128.

${ }_{63}$ Joseph Pérez, La revolución de las Comunidades de Castilla (1520-1521), Siglo XXI, Madrid, 1977, p. 483.
}

Hispania Sacra, LIX

119, enero-junio 2007, 85-140, ISSN: 0018-215-X 
esta ciudad el día del Corpus del año 1520. Había estudiado éste teología y artes en la Universidad de Salamanca, y después fue primer rector de la Universidad fundada por el cardenal Cisneros en Alcalá de Henares, y lector de teología de la catedral de Toledo, además de afamado predicador. Pero su militancia en el bando rebelde fue muy breve, puesto que pronto abandonó la radicalizada ciudad de Toledo, para refugiarse en Ajofrín, desde donde trató de servir la causa del emperador, por lo que no fue incluido en la lista de los exceptuados del perdón regio ${ }^{64}$.

La militancia de éstos y otros muchos clérigos interesados por la reflexión teológica en el bando comunero no se tradujo en la presencia abrumadora de argumentos teológicos en los documentos programáticos elaborados por las instituciones comuneras, al menos en los que han llegado hasta nosotros, que son ciertamente escasos. Sí ha podido detectarse, no obstante, una cierta influencia del pensamiento de los teólogos universitarios castellanos sobre el programa comunero, a través en concreto de la obra del teólogo escolástico Fernando de Roa. Así, en el principal documento programático del movimiento comunero que se nos ha conservado, la llamada Ley Perpetua que fue presentada para su consideración al monarca ausente en tierras del Imperio ${ }^{65}$, se pueden encontrar bastantes ecos del pensamiento de este profesor de la universidad salmantina, cuya obra se inscribía en la tradición escolástica castellana de la que habían sido exponentes principales Alfonso de Madrigal y Pedro Martínez de Osma ${ }^{66}$.

En primer lugar cabe destacar la defensa que Fernando de Roa realiza en su obra de un modelo de gobierno en que el ejercicio del poder debía quedar en manos de los representantes de las clases medias, con exclusión tanto de los sectores populares, sumidos en la indigencia, como de los miembros de la alta nobleza, detentadores de la riqueza. Para el profesor salmantino el nivel de la práctica virtuosa alcanzaba en las clases medias cotas sensiblemente más altas que en otros estratos sociales, y el régimen de gobierno ejercido por ellas era por consiguiente el que menos riesgos de convulsiones políticas encerraba. Este planteamiento, que conllevaba una valoración muy negativa del papel jugado por la nobleza en la vida política, coincide plenamente con el de los comuneros, que manifestaron de forma reiterada su animadversión hacia la alta nobleza, a pesar de que algún representante de este grupo, como es el caso del conde de Salvatierra, militó entre los rebeldes, y explícitamente incluyeron en su progra-

\footnotetext{
${ }^{64}$ Fernando Martínez GiL, art. cit., pp. 210-1.

${ }^{65}$ Los capítulos de la Ley Perpetua llevan fecha de 20 de octubre de 1520, y fueron presentados al emperador poco después por Antón Vázquez de Ávila, Sancho Sánchez Zimbrón y fray Pablo de León. Los publica fray Prudencio de SANDOval, op. cit., t. I, pp. 294-317.

${ }^{66}$ Un análisis detallado de la obra de Fernando de Roa, en que se valora su influencia sobre el programa político comunero en José Luis CASTILlo VeGAS, op. cit. En especial, pp. 127 y ss.
} 
ma la prohibición de que «ningún grande pueda tener ni tenga oficio que tocare a la hacienda y patrimonio real».

Un segundo aspecto programático fundamental en el que los comuneros coincidieron con Fernando de Roa fue el de la predilección que manifiestaron por el sistema electivo para la designación de las personas que habían de desempeñar los oficios de gobierno, y por los cargos renovables en contraposición a los hereditarios o vitalicios. En este terreno el profesor salmantino llegó a defender ideas muy radicales para la época, pues se mostró partidario del sistema electivo como más adecuado que el hereditario para la designación de la persona del monarca, siendo así consecuente con su idea de que quienes adquirían el poder por su propio esfuerzo tenían mejor aceptación que quienes lo recibían por herencia. $\mathrm{Y}$ estas ideas encontraron amplio eco en los comuneros, que hicieron de la supresión de los oficios vitalicios de regidores y su sustitución por jurados, elegidos por períodos anuales en el marco de las parroquias o cuadrillas, el punto central de su programa de reforma del régimen de gobierno local ${ }^{67}$.

La insistencia de Fernando de Roa en que la principal obligación del rey era la promoción del bien común, encontró a su vez notable eco entre los comuneros, que proclamaron hasta la saciedad su propósito de actuar «en servicio de Su Majestad y bien público de estos sus reinos». Y estos últimos también compartieron con aquél el mismo afán por limitar el poder real, poniendo freno al proceso de concentración de poder en manos del rey que estaba avanzando de forma acelerada en la Corona de Castilla.

En la obra de Fernando de Roa, como teólogo formado en la tradición escolástica que era, abundan, sin embargo, las consideraciones de tipo religioso, que están, por el contrario, totalmente ausentes tanto de la Ley Perpetua como de otros documentos que dejan percibir aspectos de la ideología política comunera. Y es esta constación la que mejor nos permite detectar la originalidad del movimiento comunero en relación con otras revueltas que tuvieron lugar por las mismas fechas en otros ámbitos de la Europa Occidental, en las que los argumentos de tipo religioso ocupaban un lugar central en los discursos programáticos. Los comuneros castellanos, a pesar de que contaron en sus filas con muchos clérigos, algunos de ellos prestigiosos teólogos, mostraron una clara inclinación por fundamentar su programa en razones de tipo filosófico-político e histórico-constitucional, en lugar de otras de índole teológica, a pesar de que éstas continuaban ejerciendo una enorme influencia en la Europa de la época. Y esto nos confirma la orientación eminentemente secular que se esforzaron por dar al movimiento de las Comunidades sus sectores dirigentes.

\footnotetext{
${ }^{67}$ Vid. Máximo Diago Hernando, «Transformaciones en las instituciones de gobierno local de las ciudades castellanas durante la revuelta comunera (1520-21)», Hispania, 214 (2003), pp. 623-56.
}

Hispania Sacra, LIX

119, enero-junio 2007, 85-140, ISSN: 0018-215-X 
Que entre éstos hubo clérigos, y fueron ellos los que de modo más activo participaron en la elaboración de los documentos programáticos y propagandísticos del movimiento está fuera de duda. Así, por lo que toca a los ámbitos locales, cabe recordar algunos significativos ejemplos que corroboran esta tesis. El más conocido nos lo proporciona la ciudad de Salamanca, donde, tras la convocatoria de Cortes efectuada por el rey el 12 de febrero de 1520, un grupo de franciscanos, dominicos y agustinos, entre los que cabe destacar a fray Alonso de Bilbao, tomaron parte muy activa en la redacción del programa de reivindicaciones que habían de presentar en Santiago de Compostela los procuradores designados por esta ciudad para representarla en Cortes, que fue además puesto en conocimiento de las otras ciudades con representación en Cortes, para animarlas a que lo adoptasen ellas también, y por esta vía se convirtió en el principal programa de oposición política al rey en el momento inmediatamente anterior al estallido de la revuelta comunera ${ }^{68}$.

Otro testimonio menos conocido lo encontramos en la ciudad de Jaén, donde el ministro del convento de la Trinidad parece que tuvo una importante intervención en la redacción de los capítulos que esta ciudad dio a los procuradores que envió a la Junta de Ávila a comienzos de septiembre de $1520^{69}$. Y un papel muy parecido pudo jugar en Madrid un enigmático personaje llamado fray Bernardino, quien, además de participar activamente en los órganos de gobierno local durante los meses de la revuelta, consta que intervino en la redacción de cartas que las autoridades madrileñas dirigieron a las de otras ciudades próximas, como Toledo o Segovia ${ }^{70}$.

Por su parte también debió ser muy intensa la participación de miembros del clero, y en particular de los frailes de las Órdenes Mendicantes, en las tareas de elaboración de documentos programáticos y propagandísticos en las instancias de gobierno central del movimiento comunero, es decir, en el entorno de la Santa Junta, que tuvo fijada sucesivamente su sede en Ávila, Medina del Campo, Tordesillas y Valladolid. Desde esta perspectiva cabe destacar la figura de Fray Pablo de Villegas, prior de Santo Domingo de León, quien fue precisamente uno de los comisionados por la Junta para presentar al rey en Flandes los capítulos de la Ley Perpetua, y destacó después por sus posturas exaltadas e intransigentes, contrarias a toda negociación con la nobleza realista. Fue este fraile, que se formó en el convento dominico de Salamanca, donde profesó en 1492, un individuo con fuertes inquietudes reformadoras, que dedicó una parte impor-

\footnotetext{
68 Vid. Joseph Pérez, La revolución de las Comunidades..., pp. 142-4.

${ }_{69}$ Pedro Antonio Porras Arboledas, La ciudad de Jaén y la revolución de las Comunidades de Castilla, Instituto de Estudios Gienenses, Jaén, p. 54.

70 Vid. Máximo Diago HeRnando, «Realistas y comuneros en Madrid en 1520 y 1521. Introducción al estudio de su perfil sociopolítico», Anales del Instituto de Estudios Madrileños, 45 (2005). En prensa.
} 
tante de su actividad al apostolado misionero. Beltrán de Heredia lo cuenta entre los que propugnaron una reforma en Castilla inspirada en el modelo de Savonarola, a quien imitó en sus violentas diatribas contra ciertos abusos de clérigos, religiosos y nobles ${ }^{71}$. Pero ningún indicio nos permite sostener que durante los meses en que se entregó en cuerpo y alma a la causa comunera se esforzase por llevar a la práctica un programa de reforma radical de las costumbres comparable al propiciado por el dominico florentino, imprimiendo una orientación decididamente religiosa al programa reivindicativo de la Junta, en cuyas sesiones tomó parte muy activa, sino que todas las informaciones de que disponemos nos lo muestran moviéndose en el terreno más estrictamente político, o, si se prefiere, secular. De hecho en la trayectoria de este inquieto dominico pueden advertirse ciertas contradicciones que dificultan la tarea de emitir un juicio sobre su orientación ideológica. Y en concreto resultan particularmente sorprendentes las declaraciones que hace en el folio 97 de su única obra, titulada Guía del cielo, acerca de la obediencia debida a los príncipes temporales, incluso aunque fuesen infieles, que revelan una actitud muy diferente de la que él observó durante los primeros meses del año 1521 hacia el rey Carlos I ${ }^{72}$.

En relación a la valoración de la participación de clérigos y frailes en el movimiento comunero, y de la influencia por ellos ejercida sobre su orientación ideológica, a través de su participación en la elaboración de su programa, se ha planteado entre los investigadores una cierta controversia a la hora de determinar si dicho movimiento tuvo un carácter conservador o revolucionario. Quienes defienden que en él predominó la orientación conservadora, e incluso reaccionaria, han llamado la atención sobre la presencia entre los rebeldes de clérigos y frailes que se destacaron por sus ideas antierasmistas, y defendieron un tipo de religiosidad de corte tradicional, muy alejada de los planteamientos renovadores que se abrieron camino en Europa más allá de los Pirineos desde comienzos del siglo XVI. Entre los investigadores que más han destacado este aspecto de la revuelta comunera cabe mencionar a Marcel Bataillon, quien identificó a varios de eclesiásticos comuneros que fueron virulentos enemigos del erasmismo, y al mismo tiempo defendió la tesis de que en las revueltas tomaron parte muy activa las masas fanatizadas, impregnadas de una religiosidad de tipo antierasmiano ${ }^{73}$. Y también Gregorio Marañón apeló al argumento de la presencia de frailes antierasmistas en las filas comuneras para justificar su calificación del movimiento de las Comunidades como xenófobo y retrógrado.

71 Vicente Beltrán de Heredia, Las corrientes de espiritualidad entre los dominicos de Castilla durante la primera mitad del siglo XVI, Salamanca, 1941, pp. 31 y ss.

72 Ibidem, p. 32. Vid. también L.A. Getino, Vida e ideario del maestro fray Pablo de León, verbo de las Comunidades castellanas, Salamanca, 1935.

${ }^{73}$ Marcel Bataillon, Erasmo y España, Méjico, 1950, vol. I, p. 260 y II, p. 15.

Hispania Sacra, LIX

119, enero-junio 2007, 85-140, ISSN: 0018-215-X 
En una línea interpretativa de signo radicalmente opuesto, José Antonio Maravall, sin embargo, sin negar la evidencia de que hubo algunos comuneros antierasmistas, de entre los que destaca a fray Bernardino, enemigo declarado de Juan de Vergara, considera más significativa la presencia en el bando rebelde de típicos erasmistas, muchos de ellos procedentes de la Universidad de Alcalá de Henares ${ }^{74}$, que estaría en consonancia con el carácter modernizador, aunque preferentemente en el terreno político más que en el religioso propiamente dicho, que él atribuye al movimiento. Y en esta misma línea interpretativa se sitúa la obra de José C. Nieto, quien no sólo no considera que los militantes comuneros abogasen por un tipo de religiosidad de carácter conservador, sino que por el contrario entiende que el triunfo de esta revuelta habría permitido la consolidación en territorio hispano de una protorreforma que, como en Alemania, habría propiciado un rápido avance de la libertad de pensamiento ${ }^{75}$.

La escasez de informaciones que tenemos a nuestra disposición para conocer en detalle las ideas que en materia religiosa defendió el movimiento comunero en su conjunto, y los individuos y grupos que lo apoyaron, en particular, no facilita la tarea de tomar partido en esta disputa. Sí conviene insistir, no obstante, en advertir que en dicho movimiento, a diferencia de lo que estaba ocurriendo por aquellas fechas al otro lado de los Pirineos, en las ciudades centroeuropeas, no se entró apenas a dilucidar problemas de tipo religioso, que no tenían prioridad en la agenda. Por este motivo pudo darse, a juicio de Joseph Pérez, el fenómeno, sólo aparentemente contradictorio, de que en los años 1520 y 1521 algunos frailes defendiesen teorías políticas de talante modernizador, y estos mismos individuos poco tiempo después, en 1525, mostrasen una actitud reaccionaria en materia religiosa, declarando su hostilidad a las ideas reformadoras de Erasmo ${ }^{76}$. Pero la verdad es que sabemos muy poco sobre la identidad de estos frailes, comuneros y al mismo tiempo antierasmistas, más allá de lo que dijo en su momento Bataillon sobre figuras como fray Juan de San Vicente y fray Bernardino de Flores, a las que quizás se podría añadir la más compleja de fray Pablo de Villegas ${ }^{77}$.

\footnotetext{
74 J.A. Maravall, Las Comunidades de Castilla, Madrid, Alianza Universidad 1979, p. 194.

75 José C. Nieto, El Renacimiento y la otra España: Visión cultural y socioespiritual, Ginebra, Droz, 1997.

76 Vid. Joseph PÉREZ, La revolución de las Comunidades..., p. 500.

77 Beltrán de Heredia destaca que, aunque en las obras de fray Pablo y Erasmo pueden detectarse algunas sorprendentes coincidencias, ambos estaban separados por un abismo espiritual. Vicente BELTRÁN DE HEREDIA, op. cit., pp. 35 y 47.
} 
LA ACTIVIDAD POLİTICA DE LOS CLÉRIGOS DURANTE LA REVUELTA COMUNERA

Participación de los clérigos en los órganos de gobierno local durante los meses de la revuelta

La normativa vigente en la Corona de Castilla a fines de la Edad Media prohibía que los miembros del estamento eclesiástico pudiesen desempeñar cualquier tipo de oficio en las instituciones de gobierno local, incluido el de escribano, y tampoco contemplaba la posibilidad de que pudiesen designar un procurador para que representase sus intereses en las asambleas concejiles ${ }^{78}$. En la práctica, sin embargo, en casos excepcionales estas rigurosas prohibiciones dejaron de observarse, como nos lo demuestra, por ejemplo, el hecho de que un comendador de la Orden de Calatrava llegase a ser recibido como regidor de la ciudad de Soria a principios del siglo XVI, tras haber sido nombrado directamente por el rey. Pero, en cualquier caso, quienes lograron burlar las prohibiciones fueron siempre clérigos de órdenes menores, que llevaban a prácticamente todos los efectos vida de laicos.

En las vísperas del estallido de la revuelta comunera esta situación comenzó, sin embargo, a verse profundamente alterada, debido a que, en algunas de las principales ciudades del reino, clérigos de órdenes mayores y frailes de las Órdenes Mendicantes pasaron a tomar parte activa en las asambleas concejiles. Uno de los primeros testimonios del fenómeno nos lo proporciona la ciudad de Burgos, donde fue denunciada la presencia de un fraile en las sesiones del regimiento a fines de diciembre de $1519^{79}$. Pocos meses después fue en Salamanca donde, como ya hemos adelantado, varios frailes de las Órdenes Mendicantes asumieron un papel protagonista en la preparación del cuaderno de instrucciones que habían de llevar a las Cortes de Santiago los dos procuradores designados por la ciudad para que la representasen en dicha asamblea. Y por estas mismas fechas, concretamente el 19 de febrero de 1520, el cabildo de la catedral de León nombró a los canónigos Juan de Benavente y Juan de las Alas para que entendiesen en «los negocios de la comunidad desta cibdad» ${ }^{80}$.

Fue, sin embargo, a partir del verano del año 1520, cuando la extensión de la revuelta a la mayor parte de las ciudades de la meseta impulsó importantes

\footnotetext{
${ }^{78}$ Sobre los duros enfrentamientos a que la indisposición del concejo de Calahorra a admitir en sus reuniones a un procurador del deán y cabildo de la catedral dio lugar en esta ciudad riojana durante el reinado de los Reyes Católicos Vid. Máximo Diago Hernando, «Clérigos y laicos en la lucha por el poder en la ciudad de Calahorra a fines de la Edad Media: Los conflictos entre los oficiales del concejo y el cabildo de la catedral», Berceo, 148 (2005), pp. 98-102.

79 Joseph PÉREZ, La revolución de las Comunidades..., p. 142

${ }^{80}$ Eloy Díaz-JiméNeZ y MolledA, Historia de los comuneros de León y de su influencia en el movimiento general de Castilla, Madrid, 1916, pp. 125 y 167.
} 
cambios en la composición de sus órganos de gobierno local, que permitió por primera vez el acceso sin restricciones a los mismos de los miembros del estamento eclesiástico, que en bastantes casos pasaron a desempeñar en su seno un muy activo papel político. Así, por ejemplo, tenemos constancia de que en la ciudad de Cuenca el concejo y el cabildo de la catedral llegaron a un acuerdo el 18 de septiembre de 1520 , por virtud del cual a partir de aquella fecha dos canónigos podrían asistir con regularidad a las reuniones ordinarias y extraordinarias del concejo, a cambio de que en contrapartida dos laicos representantes de este último, en concreto un regidor y un jurado, pudiesen asistir a su vez a la reuniones del cabildo. Pero lo canónigos conquenses hicieron uso de este derecho durante muy poco tiempo, apenas un mes, ya que a partir de los sucesos ocurridos en la ciudad el día de la fiesta de San Lucas, 18 de octubre, dejaron de asistir a las reuniones concejiles ${ }^{81}$.

En Madrid, por su parte, en la primera asamblea de carácter abiertamente rupturista que celebró el ayuntamiento el 18 de junio de 1520, que fue presidida por Juan Zapata como oficial de la justicia que había sustituido al corregidor nombrado por el rey, nos consta que estuvo presente un personaje llamado fray Bernardino, quien, además, fue designado para que, junto con el bachiller Castillo y el regidor Francisco de Herrera, redactase las respuestas que se habían de dar a las cartas que las ciudades de Toledo y Segovia habían enviado a la de Madrid, probablemente invitándola a sumarse a la revuelta por ellas iniciada. Y más adelante este mismo fraile continuó desempeñando un activo papel en las tareas de gobierno local, pues su firma figura en varios documentos de la Comunidad madrileña ${ }^{82}$.

En Zamora, según el testimonio del canónigo Diego de Valencia, asistieron con regularidad a los ayuntamientos durante los meses de gobierno comunero tanto representantes del cabildo de la catedral como frailes de todas las Órdenes Mendicantes establecidas en dicha ciudad ${ }^{83}$. Y, en Salamanca, el deán y el prior del cabildo de la catedral representaron como diputados al estamento eclesiástico en las asambleas de concejo durante los meses en que la ciudad se gobernó por Comunidad, según testimonia, entre otros documentos, la carta de poder que se otorgó en mayo en 1521 para acudir a solicitar ante los gobernadores el perdón.

\footnotetext{
${ }^{81}$ Máximo Diago Hernando, «El conflicto de las comunidades en Cuenca (1520-1522)», Chronica Nova, pp. 45-7.

82 Timoteo Domingo Palacio, Documentos del Archivo General de la villa de Madrid, Madrid, 1909, t. IV, p. 458.

${ }^{83}$ Vid. Memorial exculpatorio del canónigo Diego de Valencia, dirigido al cardenal Adriano, y presentado en Logroño, 10-VII-1521, en AGS, Cámara-Memoriales, 139-329. En dicho memorial sostuvo que había sido compelido «a asistir en los ayuntamientos que en la dicha çibdad se hazían juntamente con los religiosos de todas las ordenes y el deán mi colega, y esto para efecto de estorvar que no se hiziesen las muertes de onbres, derribamientos de casas y otras desórdenes que se ofrecían...».
} 
La situación en Ávila fue bastante más compleja. Así, tenemos constancia de que el 2 de julio de 1520 el cabildo de la catedral designó a tres de sus miembros, el deán, el arcediano de Bonilla, y el licenciado Alonso Escudero, canónigo, «para que vayan al regimiento y con los diputados por ellos e por la comunidad conferir con ellos todo lo que sea servicio de Dios e honra de la dicha iglesia y de los dichos señores deán e cabildo e de toda la clerezía» ${ }^{84}$. Pero a las pocas semanas, en concreto el 14 de agosto, por motivos insuficientemente precisados, este mismo cabildo procedió a la revocación formal del poder que había otorgado a los tres referidos clérigos, prohibiéndoles que en adelante asistiesen tanto a las sesiones de la asamblea comunera local, como a las de la asamblea de procuradores de varias ciudades castellanas con voto en Cortes, encabezadas por Toledo, que hacía pocos días había iniciado sus sesiones también en Ávila ${ }^{85}$. En la asamblea del cabildo del día siguiente, 15 de agosto, se mitigó un poco el alcance de esta prohibición, al autorizarse a estos tres individuos a que pudiesen asistir a la congregación de la ciudad, pero sólo a título personal y no en calidad de diputados del cabildo, con la condición, además, de que, pasado un plazo de tres días, dejasen de hacerlo ${ }^{86}$. Pero tanto el deán, Alonso de Pliego, como el arcediano, Vicente de Villalva, se apresuraron a presentar apelación de estos mandamientos, según queda constancia en el acta de la sesión capitular de 18 de agosto ${ }^{87}$, produciéndose a continuación su ruptura con el cabildo, de modo que en adelante ambos, y muy en particular el deán, continuaron participando activamente en las instituciones comuneras, mientras que el cabildo como corporación, y la mayor parte de sus integrantes a título personal, se mantuvieron plenamente al margen de la revuelta, y evitaron tomar parte en las tareas de gobierno local.

En la ciudad de Valladolid está por su parte ampliamente constatada la presencia en las sesiones del principal órgano de gobierno local durante los meses de la revuelta, conocido con el nombre de «junta», de varios clérigos, tanto regulares como seculares. Entre los primeros se ha de destacar la figura del maestro fray Alonso de Bustillo, quien fue asistente asiduo a las sesiones de dicha asamblea, en las que gozó de gran influencia, hasta el punto de que se le reconoció expresamente el derecho a poder participar en las votaciones ${ }^{88}$. Y, por lo que toca a los clérigos seculares, también tenemos constancia de que a las se-

\footnotetext{
${ }^{84}$ Andrés SÁNCHEZ SÁNCHEZ, Resumen de actas del cabildo catedralicio de Ávila (1511-1521), t. I, Ávila, 1995. Nº . 481. Sesión de 2-VII-1520. A esta decisión se opusieron el doctor Ayala y el canónigo Manzanas.

${ }^{85}$ Ibidem. N N$^{\circ}$. 509. Sesión de 14-VIII-1520, que fue presidida por el arcediano de Olmedo, Álvaro Carrillo, en ausencia del deán.

${ }^{86}$ Ibidem. $\mathrm{N}^{\circ} .510$.

${ }^{87}$ Ibidem. $\mathrm{N}^{\circ} .512$.

88 Joseph PÉrez, La revolución de las Comunidades..., pp. 511-12.
} 
siones de esta junta comunera local asistieron, con desigual frecuencia, al menos tres miembros destacados del cabildo de la colegiata de Santa María la Mayor, en concreto el prior, el maestrescuela y el canónigo Martín de Santander ${ }^{89}$. Pero desconocemos si lo hicieron con el consentimiento del cabildo en pleno, o si por el contrario se reprodujo también allí una situación parecida a la que acabamos de describir para Ávila.

Por lo que toca a otras ciudades en las que también se impuso con rotundidad el triunfo de la causa comunera disponemos de menos informaciones relativas a la participación de clérigos en los órganos de gobierno local. Así, en el caso de Segovia, sólo disponemos de vagas referencias al papel desempeñado por el sacerdote Antonio Meléndez, quien al parecer presidía los debates de la junta comunera local ${ }^{90}$. En Palencia simplemente nos consta que el chantre de la catedral formaba parte de la junta de guerra ${ }^{91}$. Y, en otros casos, sólo podemos deducir la presencia de clérigos en los órganos de gobierno local por la propia terminología empleada en los documentos por ellos emitidos. Es el caso de León, donde dichos documentos se otorgaron en nombre de los «regidores, caballeros, hidalgos y diputados de los señores de la iglesia mayor de la dicha ciudad y de la honrada comunidad de la ciudad de León» ${ }^{92}$, y probablemente también de Soria, donde una carta enviada por el concejo al comendador Aguilera el 5 de octubre de 1520 fue otorgada en nombre de los «caballeros, concejo, justicia, regidores y diputados de todos los estados de la noble ciudad de Soria» ${ }^{93}$.

Por lo demás, la actividad política de los clérigos en los meses de la revuelta comunera en los ámbitos locales no quedó circunscrita a su participación en los órganos de gobierno local sino que también tuvo otra destacada vertiente en su actuación como agentes propagandísticos, a la que ya nos hemos referido al dar cuenta del papel de la predicación en la vida política castellana de estos años.

\section{Clérigos en los órganos de gobierno central comunero}

La incorporación de clérigos a los órganos de gobierno local de muchas ciudades castellanas fue una de las principales novedades que en el orden institucional trajo consigo la revuelta comunera. Pero otra tanto o más importante radicó en la asunción por miembros de este mismo estamento de la representa-

\footnotetext{
${ }^{89}$ DANVILA, II, pp. 561-2

90 Joseph PÉREZ, La revolución de las Comunidades..., p. 513

91 DANVILA, III, p. 525.

92 Eloy DíAZ-JimÉneZ y MolledA, op . cit., pp. 227-8.

93 Danvila, II, pp. 429-30.
} 
ción de las sociedades políticas urbanas en el principal órgano de gobierno central puesto en funcionamiento por el régimen comunero, la Santa Junta. Esta institución tuvo en su origen el carácter de asamblea extraordinaria de Cortes, que, en lugar de haber sido convocada por el rey, como era preceptivo, se reunió por iniciativa de las propias ciudades en ella representadas, aunque pronto comenzó a asumir funciones en materia de gobierno y administración de justicia que no eran propias de una asamblea de Cortes, sino del rey y del Consejo Real.

A la Santa Junta sólo enviaron procuradores las ciudades que tenían reconocido voto en Cortes, que eran a comienzos del siglo XVI tan sólo dieciocho en el conjunto de la Corona de Castilla. Pero, mientras que, por lo que respecta a las asambleas de Cortes, no se contemplaba la posibilidad de que clérigos pudiesen ser designados como procuradores en representación de alguna de estas ciudades, nos consta que un alto porcentaje de las que enviaron procuradores a la Santa Junta incluyeron entre los mismos a algún miembro del estamento eclesiástico. Así la ciudad de León envió a dos procuradores procedentes de este estamento, el prior del convento de Santo Domingo, maestro fray Pablo de León, y Juan de Benavente, canónigo de la catedral; la de Salamanca a fray Diego de Almaraz, comendador de la Orden de San Juan; la de Toro al abad de la colegiata, Pedro González de Valderas, y la de Soria al deán de la colegiata, Hernán Yáñez de Morales ${ }^{94}$.

De estos clérigos que asumieron la representación de las ciudades en la Santa Junta no todos mostraron un mismo grado de compromiso en el apoyo a la rebelión, sino que pueden advertirse fuertes diferencias entre unos y otros. Entre los menos comprometidos habría que destacar al soriano Hernán Yáñez de Morales, quien, a pesar de que en un primer momento tomó parte activa en la firma de provisiones expedidas por la Junta, y fue designado para el desempeño de algunas delicadas misiones, como la de dictaminar sobre el estado de salud de la reina, pronto deja de ser mencionado en la documentación comunera, por lo que presumimos que debió regresar tempranamente a Soria, donde nos consta que se encontraba en enero de 1521 . Y buena prueba de que quedó muy poco comprometido por el apoyo prestado a la rebelión nos la proporciona la constatación del hecho de que no se le impuso ningún tipo de castigo por los vencedores realistas ${ }^{95}$.

\footnotetext{
${ }^{94}$ Máximo Diago HeRnANDo, «La representación ciudadana en las asambleas estamentales caste1lanas: Cortes y Santa Junta comunera. Análisis comparativo del perfil sociopolítico de los procuradores», Anuario de Estudios Medievales, 34/2 (2004), pp. 645 y ss.

${ }_{95}$ Más detalles sobre la trayectoria de este personaje en Máximo Diago Hernando, «Las ciudades castellanas contra Carlos I: Soria durante la revuelta de las comunidades», Celtiberia, 94 (2000), pp. 125-184.
}

Hispania Sacra, LIX

119, enero-junio 2007, 85-140, ISSN: 0018-215-X 
Por contraste, entre los clérigos designados por las ciudades como procuradores para que las representasen en la Santa Junta, se ha de destacar, por el apoyo que prestó a la causa de los rebeldes, la figura del procurador leonés, fray Pablo de Villegas, prior del convento de Santo Domingo de León. Ya antes de acudir a Tordesillas como procurador, este inquieto dominico había dado buena muestra de sus inclinaciones procomuneras. En concreto tuvo un notable protagonismo en los disturbios que se desencadenaron en la capital leonesa tras el regreso en junio de 1520 del conde de Luna, que había sido procurador en las Cortes de Santiago-La Coruña, llegando a colocarse como capitán al frente de un grupo de personas que se apoderaron por la fuerza del palacio del conde ${ }^{96}$.

Más adelante, después de ser designado por la ciudad de León como uno de sus procuradores en la Junta de Tordesillas, desarrolló en el seno de esta asamblea una intensa actividad, llegándosele a encomendar el desempeño de importantes misiones diplomáticas. Así, en primer lugar, cabe destacar que encabezó una delegación enviada por la Junta para negociar con el Almirante hacia noviembre de $1520^{97}$. Y más adelante fue uno de los comisionados por esta asamblea para trasladarse a tierras del Imperio con objeto de presentar a la consideración del rey los capítulos de la llamada «Ley Perpetua», que recogían las principales reivindicaciones de los rebeldes comuneros. En el transcurso de este viaje consiguió entrevistarse en Lovaina con el obispo de Córdoba, quien le transmitió la nula disposición del rey a la negociación, hasta el punto de llegar a amenazarle con la cárcel. Y como consecuencia se apresuró a regresar a Valladolid, donde contribuyó decisivamente al endurecimiento de las posturas de la Junta, que había pasado a fijar allí su sede tras la conquista de Tordesillas por las tropas realistas, adoptando una actitud exaltada e intransigente, contraria a todo proyecto de negociación y tregua con los grandes, a quienes aspiraba a destruir. El cardenal Adriano y el Almirante le atribuyeron, en efecto, en cartas enviadas al emperador, gran parte de la responsabilidad en el endurecimiento de la actitud de los rebeldes, precisamente en un momento en que ya se habían iniciado tratos con ellos 98 . Y esta radicalización de su postura a comienzos del año 1521, si bien por un lado le ganó numerosas simpatías entre los sectores populares vallisoletanos, por otro contribuyó sin duda a que los dirigentes de la ciudad de León, cada vez menos proclives al extremismo, se fuesen distanciando de él, hasta el punto de llegar a decidir su suspensión como procurador de la ciudad en la Junta a

\footnotetext{
96 Eloy DÍAZ-JIMÉNEZ Y MolledA, op. cit., p. 95.

97 Joseph PÉREZ, La revolución de las Comunidades..., p. 247.

98 Eloy DíAz JimÉNEZ, op . cit. pp. 129 y ss. Vid. también Joseph PÉREZ, La revolución de las Comunidades..., p. 302.
} 
comienzos de abril de 1521, y su sustitución por dos nuevos procuradores, el bachiller Francisco Díez y Juan de Quirós ${ }^{99}$.

La presencia de clérigos en el principal órgano de gobierno central de los comuneros no quedó circunscrita en cualquier caso a los referidos procuradores de las ciudades de León, Salamanca, Toro y Soria, sino que parece que también participaron en sus sesiones otros clérigos, sobre todo frailes de las Órdenes Mendicantes, si concedemos crédito a la afirmación del cronista Sandoval, según el cual en la Junta había, además de los procuradores, caballeros y capitanes, «muchos frailes graves y dotos, aunque no bien mirados», y estos últimos pudieron ejercer incluso el derecho de voto ${ }^{100}$.

De hecho tenemos constancia de que la Santa Junta encomendó con relativa frecuencia algunas de las más delicadas misiones políticas y diplomáticas a miembros del clero que no formaban parte de dicha asamblea en calidad de procuradores de las ciudades. Uno de los ejemplos más notables nos lo proporciona fray Alonso de Medina, maestro en teología, a quien en septiembre de 1520 la Junta de Tordesillas envió como embajador a Valladolid, para ganar apoyos entre la población de esta ciudad a fin de conseguir el apresamiento de todos los miembros del Consejo Real, y que esta institución quedase suspendida en el desempeño de sus funciones. Y, en cumplimiento de esta misión, pronunció violentos sermones en las iglesias vallisoletanas contra los miembros del Consejo, desplegando una intensa labor propagandística a favor de la causa comunera, que, no obstante, tardó en dar los apetecidos frutos, ante la resistencia que amplios sectores de la sociedad política vallisoletana ofrecían a que se cumpliesen los designios de la Junta respecto a la que entonces era la principal institución de gobierno del reino, el Consejo Real.

Más adelante este mismo fraile participó en un intento de desplazar de sus posiciones de poder a los sectores moderados de la Comunidad de Valladolid, con el infante de Granada a la cabeza, que tuvo lugar en la segunda mitad de octubre de 1520, con intervención del obispo de Zamora, pero que fracasó, saldándose con la ejecución de dos de los conspiradores, un barbero y un bonete-

\footnotetext{
${ }^{99}$ En carta enviada por la ciudad de León a la Junta de Valladolid el 9-IV-1521 se informaba del envío como procuradores del bachiller Francisco Díez y Juan de Quirós, para que sustituyesen a fray Pablo de León, a quien habían requerido para que acudiese a León porque se le necesitaba. DANVILA, III, p. 681.

100 Prudencio de SANDOVAL, op. cit. vol. I, p. 274. «Estando en la Junta todos los procuradores, caballeros, capitanes y, lo que más es de notar, muchos frailes graves y dotos, aunque no bien mirados, fueron de acuerdo que enviasen a prender al presidente y Consejo Real, y que fuesen traídos a Tordesillas, y que Valladolid los prendiese o, a lo menos, que no tuviesen en Valladolid espaldas, y que diese lugar que la Junta los prendiese y llevase. Y dicen que no faltó voto, ni aun de los frailes, porque, decían, era necesaria su prisión para bien del reino».
} 
ro ${ }^{101}$. Y, a comienzos del año siguiente, fue uno de los miembros de la delegación de la Junta que se entrevistó con el nuncio del Papa en el monasterio jerónimo de Santa María de Prado, en las afueras de Valladolid, cuando éste se ofreció como mediador para tratar de llegar a un acuerdo de paz con los virreyes ${ }^{102}$.

La práctica del envío por parte de la Junta de frailes en misiones de carácter propagandístico parece que estuvo bastante extendida, y a ella hizo expresa alusión el licenciado Lobón, cuando denunció que los de dicha asamblea habían enviado por los reinos «frailes y otras personas eclesiásticas y seglares que falsamente por trato y por palabra persuadieron a los oficiales y labradores y otras personas simples de los dichos pueblos» 103 . Las identidades de estos frailes en la mayor parte de los casos nos resultan totalmente desconocidas, pero de unos pocos sí conocemos el nombre. Entre ellos, además de los citados, podemos destacar al dominico Alonso de Bustillo, a quien en febrero de 1521 se envió desde Valladolid a la ciudad de Ávila en una misión de propaganda, para que trabajase por asegurar la permanencia de ésta en el bando comunero, y no siguiese adelante con los planes de negociación con los realistas que estaba tomando en consideración en aquellos momentos. Y otro ejemplo notorio nos lo proporciona el agustino fray Bernardino de Flores, a quien, según el cronista Saldoval, comisionó la Junta para marchar a la ciudad de Palencia a ganar apoyos para la causa comunera, tarea a la que se entregó con entusiasmo, predicando incendiarios sermones desde los púlpitos de las iglesias, por lo que poco después el cardenal Adriano ordenó su detención ${ }^{104}$.

Por otra parte, además de miembros del clero regular, también fueron empleados por la Junta para el desempeño de misiones políticas y diplomáticas miembros del clero secular que, por lo que sabemos, no formaban parte de di-

101 Informa sobre este episodio una carta que el cardenal Adriano envió al emperador desde Medina de Ríoseco, 1-XI-1520. DANVILA, II, pp. 470-4. Le comunica que, después de haber salido él de Valladolid, vinieron el obispo de Zamora y fray Alonso con alguna gente al monasterio de Prado «con trato que tenían concertado con algunos alborotadores de la villa para meterles dentro con la gente que traían y proceder contra el infante de Granada y otros servidores del rey». Pero se les resistió la entrada, y poco después fueron ahorcados dos de los que habían tomado parte en la conspiración, que eran un barbero y un bonetero.

102 Joseph PÉREZ, La revolución de las Comunidades..., pp. 289-93.

103 DANVILA, II, p. 375.

104 Prudencio de Sandoval, op. cit., p. 280. Según este autor, el cardenal Adriano, enterado del contenido de las predicaciones de este agustino ordenó apresarlo y se le pudo coger, «porque en Palencia había muchos leales que estaban escandalizados del mal ejemplo del fraile». Entonces lo llevaron preso a Medina, y luego le dieron garrote. Y de este episodio extrajo el cronista la siguiente moraleja: «Ganan y merecen esto los frailes que se meten tanto en los tratos de seglares y no guardan el recogimiento y modestia que pide el estado que profesan, renunciando el mundo y sus bullicios». Pero lo cierto es que este agustino no fue ejecutado, como sostiene Sandoval, sino que simplemente fue llevado preso a la fortaleza de Villalva, como indicaremos más adelante. 
cha asamblea en calidad de procuradores de las ciudades. Es el caso, por ejemplo, del deán de la catedral de Ávila, Alonso de Pliego, quien asumió, por encargo de la Junta, el desempeño de la importante misión diplomática de buscar el apoyo para la causa comunera del rey de Portugal, para lo cual viajó hasta Lisboa en octubre de 1520 , aunque fracasó en su intento ${ }^{105}$.

\section{PERFIL SOCIAL DEL CLERO COMUNERO}

El clero constituía en el Antiguo Régimen un estamento con un perfil social muy diversificado, en el que coexistían personas con enorme riqueza e influencia política, que llevaban un estilo de vida muy semejante al de la alta nobleza, junto con humildes capellanes que malvivían en parroquias tanto rurales como urbanas. Al hablar de las actitudes políticas de los miembros de este estamento se ha de tener muy en cuenta, por tanto, esta compleja realidad socioeconómica, y diferenciar entre los distintos subgrupos que coexistían en él. Y así conviene proceder muy en concreto al dar cuenta de la actitud del estamento clerical ante la revuelta de las Comunidades, pues si bien es cierto que entre los rebeldes figuraron clérigos procedentes de prácticamente todos los subgrupos en que éste se dividía, no cabe duda que la actitud dominante hacia la causa comunera en cada uno de los referidos subgrupos ofreció enormes contrastes de unos a otros.

\section{El clero regular}

A los frailes de las Órdenes Mendicantes se les atribuyó desde el primer momento una importante responsabilidad en el desencadenamiento de la revuelta comunera, y sobre todo en su posterior radicalización. Así nos lo testimonia, por ejemplo, la carta que la ciudad de Burgos envió a la Junta de Tordesillas, después de haber retirado su apoyo a ésta, con fecha de 11 de noviembre de 1520. En ella se denunciaba la perniciosa influencia que los frailes estaban ejerciendo en la deriva del movimiento comunero hacia posiciones radicales, en los siguientes términos:

E esos gatos religiosos debríades Señores quitar de entre vosotros, que es una causa de sembrar entre nosotros esta cizaña e vollicio. $Y$ tan desvergonçadamente y sin ningun temor predican cosas falsas y que no se deven permitir, tan escandalosas, omecidas, querríamos que llegasen por estas partes para el tema de sus sermones en ellos executar. Vosotros Señores creemos que al principio destos negocios estávades limpios e sin ninguna

105 Joseph PÉREZ, La revolución..., p. 226.

Hispania Sacra, LIX

119, enero-junio 2007, 85-140, ISSN: 0018-215-X 
mácula e santo propósito, pero estos tales, como animales dañados de mal contagioso, os irán dañando. Bien creemos la pesquisa andará tras ellos e presto serán desarraigados estos falsos apóstoles ${ }^{106}$.

Un testimonio en el mismo sentido, varios años posterior, nos lo proporciona la declaración efectuada por el corregidor de Valladolid en 1538, atribuyendo a la «ceguedad y pasión» de letrados y frailes «el fundamento principal de las abominables alteraciones pasadas»107.

Particularmente comprometidas quedaron las Órdenes de San Francisco y Santo Domingo por el importante apoyo prestado por muchos de sus miembros a la rebelión. En el caso de los dominicos en concreto su imagen quedó tan dañada que el propio Condestable consideró preciso interceder en persona ante el emperador en su favor, haciéndole ver que:

La rraiz de la rrebuelta destos Reynos an causado conversos, los quales por la misma causa que hizieron aquello desean destruyr la orden de Santo Domingo, ques la que les haze la guerra. Esta rreligion se recela que porque algunos frayles an pedricado contra vuestro servicio los quieran poner en mal con V.Mt. Y aunque es verdad que algunos an enojado, tambien ay otros que an servido, sy como es el general que prudentemente los a desviado y apartado y castigado bien los errados, y otros muchos rreligiosos que con grandissimo trabajo y peligro de sus personas an servido muy bien ${ }^{108}$.

El número de dominicos que por su participación en la rebelión fueron expresamente excluidos del perdón del rey fue, no obstante, relativamente reducido, ya que tan sólo merecieron este tratamiento cuatro individuos, fray Alonso de Bustillo, fray Pablo de León, fray Alonso de Medina y fray Alonso de Villegas. Pero no cabe duda de que éstos representaron sólo la «punta del iceberg», y que los comprometidos por el apoyo prestado a la causa comunera debieron ser muchos más, si bien nos resulta imposible reconstruir sus trayectorias, o simplemente conocer sus nombres, porque la represión sobre ellos se debió ejercer de forma silenciosa, en el seno de la propia Orden.

Y otro tanto cabe decir respecto a los franciscanos, puesto que, por un lado, nos consta que tan sólo dos miembros de esta Orden fueron exceptuados del perdón concedido por el rey, fray Juan de Bilbao y fray Francisco de Santana. Pero, por otro lado, existen testimonios recriminatorios contra los miembros de esta Orden, que llevan a presumir una militancia masiva de los mismos en la revuelta. Así en una carta que el concejo de Salamanca envió al cardenal Adriano

106 DANVILA, II, pp. 374-5.

107 Cita Joseph PÉREZ, La revolución..., p. 494.

108 Danvila, IV, pp. 41-6. Carta del Condestable al emperador, fechada en Segovia, 24-V-1521. En esta carta concluía suplicando al rey que «por culpa de particulares no permita que la orden padezca y no dé credito a los que con siniestra rrelacion quisieren indinar la orden de Santo Domingo». 
en septiembre de 1521 se hizo referencia a ellos como revolucionarios tan peligrosos que merecían ser llamados «diablos del infierno», y que debían ser severamente castigados por el enorme daño que habían causado ${ }^{109}$.

Por otra parte, sabemos que tanto de esta ciudad como de la de Toro, después de la batalla de Villalar, muchos frailes comuneros huyeron atemorizados, siendo acogidos por el provincial de Santoyo, de la Orden de San Francisco, padre de Zumarraga ${ }^{110}$. Por consiguiente no consideramos improbable que fenómenos semejantes de huida masiva de frailes comuneros, especialmente dominicos y franciscanos, tuviesen lugar en otras ciudades a raíz del retorno de las mismas a la obediencia regia, y que sus nombres nos resulten desconocidos por haberse hecho recaer sobre ellos el peso de la represión de forma silenciosa, en el interior de sus comunidades.

De hecho el estallido de la revuelta comunera había introducido un importante factor de inestabilidad y desasosiego en la vida de los conventos, donde salieron a la luz conflictos internos que es probable que se hubiesen estado gestando desde hacía tiempo. Esta evolución fue favorecida por la propia ingerencia de las instituciones comuneras, y en concreto de la Junta de Tordesillas, en asuntos de gobierno interno de las Órdenes Mendicantes. Así, sabemos que la Junta expidió provisiones ordenando el destierro de Fray Francisco de Zafra, provincial de la Orden de San Francisco de la provincia de Santiago, y de otros frailes de esta misma Orden, que fueron consiguientemente suspendidos de sus cargos y oficios en sus conventos. Con esta forma de proceder la Junta proporcionó una excusa a los frailes más propensos a la rebelión para hacerse con el control de sus conventos, en contra del provincial, o, en caso de no poder alcanzar este objetivo, sencillamente para abandonar el convento y dedicarse sin cortapisas fuera de él a la agitación política. Por este motivo las autoridades realistas reaccionaron con prontitud, expidiendo en Burgos el 7 de noviembre de 1520 una provisión en que se desautorizaban las referidas cartas y mandamientos de la Junta de Tordesillas, recordando que los procuradores de ésta eran «personas privadas», que no tenían poder para hacer nada de lo que pretendían ${ }^{111}$. Pero existen motivos para sospechar que hasta mucho después de Villalar la inestabilidad debió continuar reinando en el seno de los conventos de las Órdenes Mendicantes, en los que los conflictos desatados entre frailes comuneros y realistas tardarían bastante tiempo en apaciguarse del todo. Y no parece muy probable que a la hora de restablecer el orden en estas comunidades

109 Danvila, IV, pp. 502-4. Carta de la ciudad de Salamanca al cardenal Adriano, de 13-IX-1521.

110 Así se denuncia en la carta enviada por la ciudad de Salamanca al cardenal Adriano, en 13-IX1521. La publica DanVILA, IV, pp. 502-4.

111 AGS, RGS, XI-1520.

Hispania Sacra, LIX

119, enero-junio 2007, 85-140, ISSN: 0018-215-X 
no se ejerciese cierta represión sobre quienes con más decisión habían militado en el derrotado bando comunero.

Además de franciscanos y dominicos, también prestaron un decidido apoyo a la causa comunera algunos fraile agustinos, de entre los cuales cabe destacar a fray Bernardino de Flores. Éste fue considerado por el cardenal Adriano como un propagandista muy peligroso, por el contenido de los sermones que había predicado «en deservicio del rey», y por ello, cuando regresaba de una misión en la ciudad de Palencia, lo hizo arrestar y llevar preso a la fortaleza de Villalva, donde permanecería recluido durante el resto del conflicto ${ }^{112}$. Otro ejemplo, bastante menos célebre, de agustino comprometido por su apoyo a la causa comunera nos lo proporciona fray Juan Bravo, acusado de haber alborotado en marzo de 1521 al pueblo de Córdoba con sermones en los que incitaba a la rebelión contra el rey. Y tan peligrosa llegó a ser considerada su actividad que el regimiento cordobés ofreció una recompensa a quien le entregase, y un individuo llamado Lope de Angulo propuso incluso que se atacase por la fuerza el monasterio de San Agustín, donde se alojaba, para prenderle ${ }^{113}$.

La contribución del resto de las Órdenes a la causa comunera fue, según todos los indicios, bastante más modesta, aunque en absoluto nula. Así, por lo que se refiere a la de San Jerónimo, que experimentó una fuerte expansión en la Corona de Castilla a fines de la Edad Media, y llegó a ser considerada sospechosa por acoger a criptojudíos, cabe destacar la actividad desplegada por fray Diego de Azpeitia, fraile del monasterio de Nuestra Señora de Prado de Valladolid. A éste se le acusó, en efecto, de haber entregado en septiembre de 1520 al barbero Francisco de Camargo una carta de creencia que traía de Juan de Padilla para el infante de Granada y los diputados de Valladolid, manifestándoles que tenía por sospechoso al marqués de Denia ${ }^{114}$. Y no debieron quedar ahí sus acciones de apoyo a la causa comunera puesto que, después de Villalar, se dio orden para que fuese apresado por los muchos «excesos que cometió en los levantamientos»115.

112 El cardenal Adriano en la carta que dirigió al emperador desde Medina de Ríoseco, 1-XI-1520, sostenía que era uno de los más malignos de entre los frailes «que andan seduziendo e incitando los pueblos con sermones», por lo cual había ordenado apresarlo, poniéndolo a buen recaudo, para que después recibiese su merecido castigo. Danvila, II, pp. 470-4. Vid. también DanVILA,V, p. 103. Real cédula de 1-IV-1522 ordenando al alcaide de la fortaleza de Villalva que entregase a dicho fraile al obispo de Oviedo. Vid. también Joseph PÉrez, La revolución de las Comunidades..., pp. 483-4.

113 DANVILA, III, p. 543.

${ }^{114}$ DANVILA, II, p. 99.

115 AGS, RGS, VIII 1521. Provisión dirigida a Francisco de Vallejo, alguacil de Casa y Corte, para que preste el auxilio del brazo secular a D. Pedro Xuárez de Figueroa y Velasco, deán y arcediano de Valpuesta, canónigo de Burgos, juez subdelegado por el Papa para proceder contra los «rebeldes y traidores» de la Junta comunera. Éste había ordenado a dicho alguacil que apresaseis a fray Diego de Azpeitia, fraile jerónimo del monasterio de Prado de Valladolid, por muchas causas que fue informado que tuvo, y excesos que cometió en los levantamientos. 
La Orden de los trinitarios, especializada en el rescate de cautivos, parece que también proporcionó al movimiento comunero algún activista, pues en concreto el ministro del convento que esta Orden tenía en Jaén sabemos que llegó a trasladarse a la vecina Andujar para animar a la población a que se sumasen a la rebelión a fines de septiembre de $1520^{116}$. E incluso una de las Órdenes Militares, la de San Juan del Hospital de Jerusalén, realizó una pequeña aportación a la revuelta, en la persona del comendador fray Diego de Almaraz, que fue procurador en la Santa Junta por la ciudad de Salamanca, y aparece incluido en la relación de exceptuados del perdón concedido por el rey.

En claro contraste con los frailes de las Órdenes Mendicantes, los monjes de las Órdenes de San Benito y del Císter, de carácter más contemplativo, no tuvieron una participación tan intensa en los acontecimientos de la vida política durante la meses de la revuelta. Pero también muchos de los monasterios de estas Órdenes se vieron afectados por el clima de inestabilidad que se apoderó entonces de todo el reino, que en algunos casos nos consta que fue aprovechado por determinados grupos de monjes, opuestos al proyecto de reforma observante que desde hacía varias décadas venía promoviendo la monarquía, para tratar de liberarse del control que sobre ellos venían ejerciendo los priores reformados que les habían sido impuestos por los reyes. Así, por lo que respecta al Císter, resulta bastante ilustrativa la denuncia presentada en abril de 1521 por el reformador de la regular observancia, que había recibido comisión para visitar los monasterios de dicha Orden, contra cuatro monjes cistercienses -fray Valeriano Olivencia, fray Bernardo Cornejo, fray Fulgencio, abad de Ovila, y fray Campuzano, abad de Sagramenia- a los que acusó de andar «fuera de orden», de no querer acogerse a los monasterios, como con ellos se había acordado, y de haber entablado contactos con la Santa Junta comunera para que les apoyase en su actitud de rebeldía ${ }^{117}$.

Por lo que toca a los monasterios benedictinos, tenemos noticia de que, a mediados del año 1521, se desencadenaron graves desórdenes en el de San Salvador de Oña, uno de los principales del reino, y en el que se había impuesto recientemente la reforma observante, que había conllevado la introducción de un régimen de vida de rigurosa clausura ${ }^{118}$. La conexión de estos desórdenes con la revuelta comunera no aparece del todo clara, puesto que las informaciones que proporcionan los documentos resultan insuficientemente explícitas a este res-

116 Pedro Antonio PorRas ArboledAs, op. cit., p. 54.

117 AGS, RGS, Burgos 14-IV-1521. Provisión dirigida a fray Valeriano Olivencia, fray Bernardo Cornejo, fray Fulgencio, abad de Ovila, y fray Campuzano, abad de Sagramenia, ordenándoles que se recojan en los monasterios.

${ }_{118}$ Sobre el largo proceso de la implantación de la reforma observante en el monasterio de San Salvador de Oña, iniciado a mediados del siglo XV, Vid. E. HERRERA ORIA, «Reforma religiosa del monasterio de Oña en el siglo $\mathrm{XV} », R A B M, 29$ (1925), pp. 55-83, 155-65 y 334-44.

Hispania Sacra, LIX

119, enero-junio 2007, 85-140, ISSN: 0018-215-X 
pecto, y plantean bastantes interrogantes a los que resulta difícil dar respuesta. Pero consideramos muy probable que la hubiese. En concreto, por una real provisión real fechada en Burgos el uno de agosto de 1521, dirigida a los alcaides de las fortalezas de Frías y Medina de Pomar, sabemos que algunos monjes opuestos al abad que entonces estaba al frente de la comunidad de San Salvador de Oña, se habían movilizado para que se tomase el edificio del monasterio por la fuerza de las armas, haciendo ver que era para que estuviese en la obediencia del rey («so color que se tenía en nuestro nombre»). Y a los requerimientos de estos monjes habían respondido los dos mencionados alcaides, miembros ambos de la clientela del Condestable, señor de Frías y de Medina de Pomar, los cuales, procedieron de inmediato a reunir gente de armas para poner en ejecución el plan. El abad había hecho saber al rey, no obstante, que estos monjes habían difundido falsas informaciones, y que actuaban exclusivamente movidos por su disconformidad con la manera en que él estaba gobernando el monasterio, como persona «celosa de la religión y del aumento del culto divino», que había procurado con todas sus fuerzas «el buen vivir en religión de los religiosos del monasterio», pues ellos tenía otro celo. Y, por este motivo, en la referida real cédula se prohibió terminantemente a los mencionados alcaides que siguiesen adelante con su intención de apoderarse por la fuerza del monasterio, y se les ordenó que dispersasen a todas las gentes de armas que habían reunido para ello ${ }^{119}$.

No cabe duda de que los monjes que habían conseguido ganarse para su causa a los alcaides de Frías y Medina de Pomar eran individuos descontentos con el régimen observante que se había impuesto en la comunidad monástica oniense, y que trataron de aprovechar la inestabilidad reinante en Castilla como consecuencia de la revuelta comunera para imponer una vuelta al régimen de vida anterior a la introducción de la observancia. Lo que ya no resulta tan claro es qué tipo de argumentos pudieron aducir para convencer a dichos alcaides, miembros de la clientela del Condestable Iñigo Fernández de Velasco, de la necesidad de tomar por la fuerza el monasterio para asegurar que éste se tuviese en nombre del rey. Cabe plantear la hipótesis de que, durante los meses de la revuelta comunera, la comunidad monástica oniense, y más en particular el abad que la presidía, hubiesen mantenido ciertos contactos con los rebeldes, que pudieran convertirles en sospechosos ante los ojos del rey, o, más propiamente, de su gobernador, el Condestable, el hombre fuerte de la región burgalesa. Pero no contamos con indicios suficientes que nos permitan afirmarlo con seguridad. Una provisión de abril de 1522 nos informa que varios monjes de Oña identificados por sus nombres fueron apresados por razón de «cierta infamia que le-

${ }^{119}$ La provisión en AGS, RGS, VIII-1521. También hay una copia de la misma en AHN, Clero, leg. 1235 . 
vantaron» contra el abad, por lo que no es descartable que tal infamia pudiese haber consistido en acusarle de haber apoyado la causa comunera ${ }^{120}$. Pero se trata de una simple hipótesis que ningún otro indicio contribuye a corroborar. De lo que no cabe duda es de que el estallido de la revuelta comunera favoreció el recrudecimiento de las disensiones en el seno de la comunidad monástica oniense, y el relajamiento de la disciplina, hasta el punto de que un grupo numeroso de monjes dio el insólito paso de abandonar el monasterio para llevar un estilo de vida propio de laicos, amparados por la protección que les dieron parientes suyos que residían en la comarca ${ }^{121}$.

El relajamiento de la disciplina en las comunidades de clero regular como consecuencia del estallido de la revuelta comunera fue un fenómeno relativamente frecuente, que se manifestó en episodios de muy diferente signo. Así, por ejemplo, en la villa de señorío de Dueñas, donde triunfó un levantamiento antiseñorial que buscó su legitimación en la causa comunera, tuvo lugar un curioso episodio de abandono en masa del monasterio de San Agustín por el prior y monjes que en él residían, que, además, se llevaron consigo gran cantidad de bienes, en particular dinero en metálico y joyas de oro y plata, que estaban allí depositadas ${ }^{122}$. Por su parte, en el monasterio de monjas dominicas de San Juan de Quijana, en Álava, el comunero conde de Salvatierra al parecer consintió el relajamiento de la disciplina interna a cambio de que se le tolerase la apropiación indebida de los bienes del monasterio, y en especial de su plata. Y este relajamiento llevó a que las monjas se atreviesen a tomar presa a una priora que los superiores de la Orden habían enviado para reformar la comunidad, manteniéndola en dicho estado de privación de libertad hasta que murión ${ }^{123}$.

120 AGS, RGS, IV-1522. Los monjes denunciados son en concreto fray Juan de Artiaga, fray Antonio de Valdivieso, fray Pedro de Carasa, fray Juan de Salazar, fray Pedro de Carranza y fray García de Robredo.

121 AGS, RGS, XI-1521. Comisión a Pedro de Gamboa, alguacil de Casa y Corte, en respuesta a la denuncia presentada por el abad de la Congregación de San Benito de Valladolid, contra algunos monjes del monasterio de Oña, quienes «por no ser corregidos y castigados de sus defectos por el abad y los otros abades que están visitando el monasterio», la habían abandonado, y habían pasado a residir en lugares de su comarca, en casas de parientes y amigos, donde eran defendidos. Se hace referencia en concreto a Fray Juan de Salazar, que se encontraba en la torre de Tamayo, donde le defendían sus parientes, que eran señores de dicha torre.

122 AGS, RGS, VII-1521. Orden para que el provincial de la Orden de San Agustín aprese al prior y frailes del monasterio de San Agustín de Dueñas, por haber abandonado todos el monasterio durante los levantamientos pasados, llevándose consigo muchos dineros y joyas de oro y plata, y otra mucha hacienda.

123 DANVILA, IV, p. 337-8. Referencia a un memorial del vicario del maestre general de los dominicos presentado en el Consejo Real.

Hispania Sacra, LIX

119, enero-junio 2007, 85-140, ISSN: 0018-215-X 


\section{El clero de rango medio: miembros de los cabildos}

Dentro del estamento clerical el grupo al que pertenecían el mayor número de exceptuados del perdón del rey es el constituido por clérigos de rango medio, que formaban parte de los cabildos de las catedrales o de las iglesias colegiales de aquellas ciudades importantes, muchas de ellas con voto en Cortes, que no eran capital de diócesis, como es el caso de Valladolid, Madrid, Soria, Toro o Medina del Campo. En efecto, a este grupo se pueden adscribir una docena de individuos, incluidos en la lista de excluidos del perdón, que son en concreto Alonso Enríquez, prior de Valladolid, Pedro González de Valderas, abad de Toro, Alonso García del Rincón, abad de Medina del Campo, Gil Rodríguez Juntero, arcediano de Lorca, Francisco Zapata, arcediano de Madrid, Juan de Collados, maestrescuela de Valladolid, Francisco Álvarez Zapata, maestrescuela de Toledo, Rodrigo de Acebedo, canónigo de Toledo, Juan de Benavente, canónigo de León, Pedro de Fuentes, chantre de Palencia, Juan Pereira deán de Salamanca, y Alonso de Priego, deán de Ávila. Y a sus nombres se podrían añadir los de algunos otros que, aunque no fueron explícitamente incluidos en dicha lista, fueron denunciados como «deservidores del rey», y llegaron a ser procesados, aunque desconocemos qué tipo de castigo se les impuso finalmente. Es el caso, por ejemplo, del canónigo de la catedral de Cuenca, Juan del Pozo, quien fue acusado de haber pronunciado públicamente «muchas palabras en deservicio del rey», por lo que en marzo de 1521 Diego Huidobro, juez apostólico subdelegado para conocer en las causas de los miembros del estamento eclesiástico acusados de comuneros, solicitó el auxilio del brazo secular para proceder a su apresamiento ${ }^{124}$.

Otro canónigo que no aparece en las listas de exceptuados, y contra el que, sin embargo, se presentaron graves acusaciones es un tal Acebes, quien fue denunciado por el licenciado Lobón, fiscal, por reunir gente de guerra en la villa de Baltanás y su comarca a favor «de los traidores de la Junta» en marzo de $1521^{125}$, y más adelante también por haber andado en compañía del obispo de Zamora, Antonio de Acuña, junto con otro clérigo, criado del obispo de Burgos,

${ }^{124}$ AGS, RGS, III 1521. Provisión a Rodrigo de Cárdenas, corregidor de Cuenca y Huete. Vid. también memorial presentado por Juan del Pozo, canónigo de Cuenca, en Logroño, 17-VIII-1521, en AGS, Cámara-Memoriales, 139-385. Reconoce que el juez subdelegado, Diego Huidobro, le había ordenado que compareciese ante él, pero había alegado que era una persona de mucha edad e impedido, y, además, por diversas causas e impedimentos había apelado del dicho juez ante el Papa. Reconsiderando su postura, manifiesta, no obstante, su disposición a apartarse de la apelación, por lo que, en consecuencia, solicita que le preste audiencia el juez.

125 AGS, RGS, III-1521. Provisión al licenciado de Paz, alcalde del Adelantamiento de Castilla, del partido de Burgos, para que proporcione el auxilio del brazo secular al protonotario Huidobro en la detención del canónigo Acebes, denunciado por el licenciado Lobón, fiscal. 
llamado Comparan, con el que, tras la derrota de Villalar, había huido a Peñafiel, llevando consigo gran número de carneros y ovejas que habían tomados en sus operaciones de rapiña por los campos de Castilla ${ }^{126}$.

La relación de clérigos de rango medio que sabemos que colaboraron en algún momento con el régimen comunero, aunque luego moderaron sus posturas, y por ello probablemente no recibieron ningún tipo de castigo después de Villalar es relativamente larga. Ya nos hemos referido al caso del dean de la colegiata de Soria, Hernán Yáñez de Morales, que fue procurador a la Junta de Tordesillas, y que, a pesar de ello, no fue incluido en la lista de exceptuados del perdón, probablemente porque se retiró muy pronto de dicha asamblea, siguiendo instrucciones de las propias autoridades sorianas. Otros ejemplos dignos de mención nos los proporcionan Diego de Valencia y otros dos canónigos zamoranos que tras la batalla de Villalar fueron llevados presos a la fortaleza de Zamora, acusados de haber colaborado con el régimen comunero, en el caso del primero por haber asistido regularmente a las sesiones de la principal institución de gobierno local durante los meses de la revuelta ${ }^{127}$.

También quedó bastante comprometido por sus actuaciones en los años 1520 y 1521 el prior de la catedral salmantina Álvaro Gómez de Jaén, a quien Cooper le presume un origen converso ${ }^{128}$. En marzo de 1521, en efecto, acudió a Valladolid ante la Santa Junta en representación de las autoridades comuneras salmantinas ${ }^{129}$. Y, más adelante, su convecino, el licenciado Martín de la Villa, le acusó de haber andado «de ciudad en ciudad alborotando los reinos»130.

Por su parte en la ciudad de Plasencia fueron varios los miembros del cabildo de la catedral que tomaron parte muy activa en los violentos enfrentamientos que allí se desencadenaron en los años 1520 y 1521, de entre los cuales cabe destacar al deán Gómez de Jerez, y al arcediano Bernardino de Carvajal. Am-

126 AGS, RGS, V-1521. Provisión al alcalde mayor del Adelantamiento de Castilla, ordenándole que detenga al canónigo Acebes y al clérigo llamado Comparan, y se apodere de los ganados que éstos habían llevado consigo a Peñafiel.

127 AGS, Cámara-Memoriales, 139-329. Memorial de Diego de Valencia, canónigo de la catedral de Zamora, dirigido al cardenal Adriano. Se presentó en Logroño, 10-VII-1521. Informa que «después de la batalla de Villalar, sin ninguna causa, estando él seguro porque de lo pasado no tenía culpa, por pasiones particulares fue preso por algunas personas seglares que a la sazón dieron las varas, y por otros que los inducían, y nos llevaron con mucha afrenta a mí y a otros dos canónigos a la fortaleza donde estuve algunos días preso».

128 Vid. Edward COOPER, «La Iglesia y los comuneros: Una interpretación anti-antiseñorial», en Fernando MARTínez Gil (Coord.) En torno a las Comunidades de Castilla. Actas del Congreso Internacional «Poder, conflicto y revuelta en la España de Carlos I», Edicones de la Universidad de Casti1la-La Mancha, Cuenca, 2002, p. 286.

${ }^{129}$ DANVILA, III, p. 524. Referencia a la carta escrita por la ciudad de Salamanca el 22-III-1521 a la Junta de Valladolid para que diese creencia al prior de la catedral.

130 Danvila, IV, pp. 99-102. Memorial del licenciado Martín de la Villa, vecino de Salamanca.

Hispania Sacra, LIX

119, enero-junio 2007, 85-140, ISSN: 0018-215-X 
bos llegaron a ser acusados de haber apoyado la causa comunera, pese a que cada uno militó en un bando diferente, de los dos que en el transcurso de estos meses se disputaron el dominio de las ciudad, el de los Carvajales y el de los Zúñiga. Pero ninguno de los dos recibió finalmente castigo por su presunta participación en la rebelión contra la autoridad monárquica ${ }^{131}$.

Y a estos ejemplos se podrían añadir otros varios, como el ya aludido del obispo de Utica, que, no obstante, no entraremos aquí a enumerar de forma promenorizada para no resultar prolijos. Esta abundancia de casos no nos debe hacer perder de vista, sin embargo, el hecho de que mayoritariamente los miembros de los cabildos de las catedrales y grandes colegiatas de las ciudades castellanas de la meseta, por no hablar de las de otros ámbitos del reino, como Andalucía o Galicia, que se mantuvieron en gran medida al margen de la rebelión, evitaron comprometerse mediante el apoyo decidido a la causa comunera, y en su lugar o bien adoptaron una postura ambigua, sobre todo en los primeros meses, o bien decidieron alinearse en el bando realista. De ahí que las relaciones de las autoridades comuneras con los cabildos en muchas de las ciudades que adoptaron una actitud de más abierta rebeldía frente a la autoridad del rey llegasen a resultar difíciles, y no exentas de tensión. Así ocurrió, por ejemplo, en León, donde ya el 15 de diciembre de 1520 el jefe comunero local, Ramir Núñez de Guzmán, denunció la actitud poco favorable hacia la causa de la Comunidad que manifestaban varios de los miembros del cabildo catedralicio ${ }^{132}$. Por su parte en el caso de Ávila las reticencias del cabildo de la catedral hacia la causa comunera quedan bien puestas de manifiesto en los acuerdos a los que llegó a partir de mediados de agosto de 1520, de retirar los poderes que había otorgado a algunos de sus miembros para que pudiesen asistir a las sesiones del principal órgano de gobierno local comunero, así como a las de la Junta de procuradores de ciudades con voto en Cortes que por iniciativa de Toledo había iniciado sus sesiones en la propia ciudad de Ávila el 1 de agosto de ese año. Y esta actitud es aún más digna de resaltar si tenemos en cuenta que llevó al cabildo a un choque frontal con su propio presidente, el deán Alonso de Pliego, que adoptó una postura de decidida militancia en el bando rebelde, $\mathrm{y}$ hubo por ello de ser desautorizado por sus propios subordinados, que en su reunión del día 21 de agosto dispusieron que en adelante no se convocase a cabildo cuando el deán mandase llamar «para las cosas de la congregaçión de la çibdad, ni de los procuradores de las otras çibdades», aunque el dicho deán ordenase a su pertiguero que realizase formalmente la convocatoria mediante el procedimiento habitual ${ }^{133}$.

131 Vid. Máximo Diago Hernando, «Las luchas de bandos como factor determinante del conflicto comunero en Plasencia (1520-1522)», Cuadernos de Historia Moderna, 31 (2006), pp. 63-89.

132 Eloy DíAZ-JiMÉNEZ Y MolledA, op. cit., pp. 167-202.

${ }^{133}$ Andrés SÁNCHEZ SÁNCHEZ, op . cit., No ${ }^{\circ}$.513. Este acuerdo fue contradicho por dos miembros del cabildo, el doctor Ayala y Juan Álvarez Pajares, quienes argumentaron que, pues el deán era presidente del cabildo, podía ejercer su derecho de convocarlo dando las órdenes oportunas al pertiguero. 
Tampoco en Toledo la presencia de varios e influyentes canónigos procomuneros llevó al cabildo a inclinarse por apoyar de forma decidida la rebelión, sino que más bien adoptó una actitud obstruccionista frente a los rebeldes, que finalmente dio lugar a que varios canónigos tuviesen que abandonar la ciudad para refugiarse en Ajofrín. Y buena prueba de que el cabildo toledano como corporación no quedó comprometido por su apoyo a la causa rebelde, sino más bien al contrario, nos la proporciona el hecho de que, una vez restablecido el poder del rey en la ciudad, fue el propio cabildo el que ejerció la represión sobre aquéllos de sus miembros más comprometidos por su apoyo a la causa comunera, como es el caso del canónigo Rodrigo de Acebedo, a quien llevaron preso a la torre de la catedral, trasladándolo después a un aposento del claustro, y por fin a su propia casa, a la vez que le embargaron los frutos de su canonjía y prebenda ${ }^{134}$.

Aclarado este extremo, podemos centrarnos a continuación en dar cuenta del perfil de aquellos miembros de los cabildos que más comprometidos quedaron por el apoyo prestado a la causa comunera, y como consecuencia fueron exceptuados del perdón concedido por el rey, para tratar de precisar los motivos que pudieron llevarles a apoyar abiertamente una causa que fue considerada con sumas reticencias, cuando no con hostilidad, por la mayoría de sus colegas. No en todos los casos disponemos de datos suficientes para reconstruir de forma satisfactoria el perfil de estos «canónigos comuneros». Sí podemos avanzar que en su mayor parte de trataba de individuos de elevado rango social, que por regla general ocupaban posiciones de primera fila en el seno de sus correspondientes cabildos, pues la mayoría eran dignidades en lugar de simples canónigos, y además procedían de reputadas familias de las oligarquías hidalgas de sus ciudades de residencia. Un ejemplo notable nos lo proporciona el deán de la catedral de Salamanca, Juan Pereira, de quien se dijo que había sido «la raíz y sustentación de los delitos de la ciudad» ${ }^{135}$. Era hijo de un influyente clérigo salmantino del mismo nombre, quien había renunciado en él el deanato de la catedral a principios del siglo XVI, a pesar de que continuó con vida hasta 1531, y que por el lado paterno estaba emparentado con destacadas familias de la oligarquía salmantina, del bando de San Benito ${ }^{136}$.

Por su parte el arcediano de Madrid, Francisco Zapata, también formaba parte de uno de los principales linajes de la oligarquía hidalga madrileña, pues era hermano del regidor Pedro Zapata, señor de las villas de Barajas y La Ala-

\footnotetext{
${ }^{134}$ AGS, RGS, V-1522. Provisión dirigida al deán y cabildo de la catedral de Toledo, a petición del canónigo Rodrigo de Acebedo.

135 Danvila, IV, pp. 95-7. Declaraciones ante el alcalde Zárate de Alonso de Acebedo, Alonso Rodríguez de Fonseca y Pedro de Anaya, en Medina del Campo, 4-V-1521.

136 Claudia Möller ReCondo, Comuneros y Universitarios: Hacia la construcción del monopolio del saber, Miño y Dávila, Madrid-Buenos Aires, 2004, pp. 229 y ss.
}

Hispania Sacra, LIX

119, enero-junio 2007, 85-140, ISSN: 0018-215-X 
meda, y del caballero Juan Zapata, capitán de la Comunidad de Madrid, que tuvo una activa participación en la guerra, al lado del capitán toledano Juan Padilla ${ }^{137}$. Y el maestrescuela de la catedral de Toledo, Francisco Álvarez Zapata, además de tener varios hermanos que fueron regidores de Toledo, y uno que sirvió como secretario a los Reyes Católicos, gozó de la plena confianza tanto del cardenal Mendoza, primero, como del cardenal Cisneros, después. Puede considerársele, por tanto, como un individuo de enorme influencia tanto en el ámbito local toledano como en el cortesano, que, no obstante, tuvo en su contra la pertenencia a un linaje de judeoconversos, que propició varios choques con la Inquisición, con el resultado del ajusticiamiento en la hoguera de su hermano, el jerónimo fray García de Zapata, prior del monasterio de La Sisla, y el inicio de un proceso contra él mismo, en el que se le imputaron algunas prácticas judaizantes ${ }^{138}$.

A este mismo encumbrado medio social presumimos que debía pertener, por sus apellidos, el prior de Valladolid Alonso Enríquez de Arellano, aunque de momento no hemos logrado reunir datos precisos sobre su filiación y biografía, pues sólo sabemos que murió en Roma dejando todos sus bienes al Hospital de Inocentes de Valladolid ${ }^{139}$. Y, aunque ocupaba una posición más modesta, también éste era el caso del canónigo de la catedral de León Juan de Benavente, pues nos consta que había conseguido casar a una hija suya, no sabemos si legítima o no, con el camarero del conde de Benavente, Álvaro de Vozmediano, lo que le sirvió para que este poderoso noble castellano intercediese después por él, logrando que el cardenal Adriano lo liberase de la prisión en que se encontraba, tras haber sido apresado junto con otros procuradores de la Junta a raíz de la conquista de Tordesillas por las tropas realistas ${ }^{140}$.

Los ejemplos aludidos nos confirman, por tanto, que los miembros de los cabildos que apoyaron la causa comunera, aunque pocos en número, fueron individuos de elevado rango y notable influencia en sus respectivas ciudades, que mantenían fuertes vínculos de parentesco con las oligarquías nobles que controlaban el gobierno de éstas, y con frecuencia compartían con ellas un mismo estilo de vida, como lo prueban las noticias relativas a sus clientelas armadas ${ }^{141}, \mathrm{y}$

137 Vid. Alonso de SANTA CRUZ, Crónica del Emperador Carlos V, Real Academia de la Historia, Madrid, 1920, vol. I, p. 348.

138 Información detallada sobre este individuo y su familia en $\mathrm{M}^{\mathrm{a}}$. del Pilar RÁBADE OBRADÓ, Los judeoconversos en la Corte y en la época de los reyes Católicos, Universidad Complutense, 1990, pp. 531-2, 542, 634-7 y 766.

139 Danvila, V, p. 554.

140 AGS, Cámara-Memoriales, 141-52. Memorial dirigido a los gobernadores por el conde de Benavente, fechado en La Puebla de Sanabria, 16-VII-1521.

141 Como ejemplo ilustrativo baste recordar que Don Juan Pereira, deán de Salamanca, solicitó en 1514 licencia a los reyes para que todas las personas que con él anduviesen pudiesen traer armas, pues, por ciertas diferencias que había tenido con el arzobispo de Santiago, éste le tenía mucho odio y enemistad. AGS, RGS, IV-1514. 
a sus hijos ilegítimos. Su perfil presenta, por lo tanto, cierto parecido con el de muchos regidores que en las ciudades de la meseta se pusieron desde el primer momento al frente de una rebelión que, en muchos aspectos, terminó persiguiendo objetivos contrarios a sus intereses. Sus motivaciones a la hora de alinearse en el bando rebelde probablemente haya que buscarlas por consiguiente en el ámbito de sus estrategias personales y familiares en pro de un incremento de su capacidad de ejercicio del poder en el ámbito local. Pero con las informaciones a nuestra disposición resulta bastante difícil realizar más precisiones al respecto, en tanto no se produzcan avances en la investigación de la problemática de las luchas por el poder en los distintos ámbitos locales del reino en estos años.

En cualquier caso, son relativamente numerosos los indicios que sugieren que, a diferencia de los frailes de las Órdenes Mendicantes, los clérigos de rango medio miembros de los cabildos que militaron en el bando comunero pronto tendieron a adoptar posiciones netamente moderadas, distanciándose de los elementos radicales. Así ocurrió, por ejemplo, en el caso del maestrescuela de Toledo, Francisco Álvarez Zapata, quien en el período final de la revuelta evolucionó claramente hacia la moderación, como bien demostró su tenaz oposición a entregar a la Comunidad toledana el oro del cabildo.

Otro ejemplo en el mismo sentido podríamos encontrarlo en la trayectoria del deán de Ávila, Alonso de Pliego, que, no obstante, no ha sido todavía suficientemente clarificada, por lo que resulta arriesgado emitir un juicio seguro al respecto. En concreto nos ha llamado la atención la noticia contenida en los libros de actas del cabildo abulense de que a fines de marzo de 1521 este clérigo fue desterrado de Ávila por la Congregación, es decir, por el órgano de gobierno comunero de la ciudad. Lamentablemente esta fuente documental no precisa las razones por las que fue impuesta tan severa pena a quien había sido uno de los principales dirigentes comuneros de la localidad, pero consideramos significativo el hecho de que éste solicitase al cabildo que, dado que se le había condenado a destierro «injustamente», no se le efectuase descuento ninguno en las cantidades que le correspondía cobrar por la asistencia a los oficios capitulares. Y el cabildo en su reunión de 26 de marzo de 1521 atendió favorablemente su petición, acordando seguir abonándole dichas cantidades, con la condición de que si se averiguase que la pena de destierro había sido justamente impuesta se les descontaría lo que correspondiese ${ }^{142}$. Esta predisposición del cabildo a atender la solicitud del deán, a quien hacía meses había prohibido de forma expresa que asistiese a las reuniones de la Congregación, hace presumir que el motivo por el que éste había sido desterrado de la ciudad no tuviese que ver con una posible radicalización de sus

142 Andrés SÁNCHEZ SÁNCHEZ, Resumen de actas del cabildo catedralicio de Ávila (1511-1521), t. I, Ávila, 1995, No. 596.

Hispania Sacra, LIX

119, enero-junio 2007, 85-140, ISSN: 0018-215-X 
posturas en relación con las dominantes entre los comuneros abulenses, sino más bien por todo lo contrario, es decir, que quizás se le desterró porque se le consideraba demasiado moderado, e incluso sospechoso de «colaboracionista» con el bando realista. Y a esta misma conclusión nos lleva la constatación de que semanas después de la batalla de Villalar le fue levantada la pena de destierro, y pudo volver a entrar libremente a la ciudad de Ávila ${ }^{143}$, pues parece bastante improbable que se hubiese procedido así si el motivo por el que se le había impuesto la pena era por considerarle demasiado radical en sus posturas.

Otro de los clérigos de rango medio exceptuados del perdón, que según todos los indicios también adoptó una actitud bastante moderada, cuando no calculadamente ambigua, durante la revuelta fue el abad de Medina y arcediano de Cuéllar, en la catedral de Segovia, Alonso García del Rincón ${ }^{144}$. Así lo sugiere en primer lugar el hecho de que el cabildo de la catedral segoviana intercediese por él ante los gobernadores, destacando que en el tiempo en que residió en Segovia sirvió al rey todo lo posible, procurando la pacificación de la ciudad ${ }^{145}$. Y en este mismo sentido apunta el hecho de que en los meses de mayo y junio de 1521 el concejo de Medina del Campo dirigiese varios memoriales al rey solicitando que no se le excluyese del perdón, con el argumento de que tanto en Segovia como en Medina había siempre procurado el sosiego y la paz, mostrándose muy riguroso contra los alterados y bulliciosos ${ }^{146}$.

\section{El bajo clero secular}

En claro contraste con lo que ocurre con el clero de rango medio de los cabildos de catedrales y colegiatas, es muy poco lo que sabemos sobre la participación de los sectores inferiores del clero secular en la revuelta comunera. A lo sumo podemos encontrar en los documentos denuncias en términos muy vagos, que dejan constancia de la participación en la rebelión de numerosos miembros del

\footnotetext{
143 Ibidem. Nº. 610. En la reunión del cabildo de 10-V-1521, se dejó constancia de que se había sabido que al deán le había sido alzado el destierro, y ya podía acudir libremente a su iglesia.

144 Cabe precisar que durante los meses de la revuelta comunera hubo dos individuos identificados como abad de Medina: el ya referido Don Alonso García del Rincón, que era además abad de Compludo, y micer Bernardino Gutiérrez, prior de Sevilla. Vid. Carlos Álvarez García, «La revolución de las Comunidades en Medina del Campo», en Historia de Medina del Campo y su Tierra. Nacimiento y expansión, Vol. I, Junta de Castilla y León, Valladolid, 1986, pp. 563-4. Según este autor, Bernardino Gutiérrez, que había ya muerto para diciembre de 1522, fue probablemente resuelto comunero y belicista convencido, pero la postura de Alonso García del Rincón, abad de Compludo, habría sido más ambigua.

145 AGS, Cámara-Memoriales, 141-412. Petición del deán y cabildo de Segovia, de 17-VI-1521, solicitando el perdón para el abad de Compludo y arcediano de Cuéllar.

146 AGS, Cámara-Memoriales, 139-256, 161-159 y 163-81.
} 
estamento clerical, sin precisar la identidad de los mismos. Es el caso, por ejemplo, de la que efectuó un regidor de Baeza, el comendador López de Valenzuela, según el cual muchas personas de las que en esta ciudad andaluza «hicieron los daños, y dieron para ello consejo, favor y ayuda» fueron clérigos ${ }^{147}$. Y otro ejemplo de denuncia en términos igualmente vagos es la efectuada por el obispo de Osma, Alonso Enríquez, quien declaró haberse enterado de que «muchos clérigos de la diócesis y de su obispado, y beneficiados en ella, y otras personas eclesiásticas del obispado» fueron «incitadores y promotores de muchos escándalos, movimientos y tiranías, y otros males que ha habido en tiempo de las Comunidades», y muchos de ellos «entendieron en persona en dichos alborotos y escándalos» 148.

A partir de estas vagas denuncias cabe ciertamente plantear la hipótesis de que en muchos lugares los clérigos seculares de posición socioeconómica más modesta se uniesen a los alborotadores. Pero, a falta de otras noticias más concretas en la documentación, resulta imposible precisar su número, identidad y motivaciones concretas. Sólo en unos pocos casos aislados disponemos de informaciones suficientes como para aventurar la identidad de algunos de estos clérigos. Podría ser el caso de Diego Ruiz de la Cámara, vecino de Medina del Campo, de quien el procurador de los regidores y caballeros hidalgos de esta villa dijo en noviembre de 1522 que había sido «uno de los principales alborotadores y deservidores del rey en los tiempos de la Comunidad», a pesar de lo cual recientemente había conseguido hacerse vicario de la villa, con el apoyo de diez o doce clérigos, en contra del procedimiento consuetudinario ${ }^{149}$.

Otro ejemplo de clérigo comunero nos lo proporciona Juan Hernández, clérigo de Anguiano, quien, según noticia proporcionada por Gutiérrez Nieto, compartió con el escribano Martín García el liderazgo del levantamiento antiseñorial que bajo bandera comunera se produjo en esta villa riojana en septiembre de 1520 contra su señor, el monasterio benedictino de Santa María de Valvane$\mathrm{ra}^{150}$. Y a este mismo perfil respondería la figura del licenciado Pedro Gutiérrez de los Ríos, clérigo de la iglesia de San Martín, en Paredes de Nava, quien fue uno de los principales incitadores a la rebelión en esta villa de señorío, que no sólo hizo que se nombrasen diputados y cuadrilleros, sino que también desplegó una intensa campaña propagandística, difundiendo en sus discursos públicos profecías que anunciaban la victoria final de las Comunidades ${ }^{151}$.

${ }^{147}$ AGS, RGS, I-1523. Provisión al licenciado Hernán Álvarez de Ribadeneira, juez de comisión.

148 AGS, RGS, VIII-1521. Provisión dirigida a todos los justicias, a petición de D. Alonso Enríquez, obispo de Osma.

149 AGS, RGS, XI-1522. Provisión al corregidor de Medina del Campo.

150 Juan Ignacio GutiéRrez Nieto, Las Comunidades como movimiento antiseñorial, Barcelona, 1973, p. 163.

151 Danvila, IV, p. 441. Vid. también Alfonso María Guilarte, El obispo Acuña. Historia de un comunero, Valladolid, 1979, p. 132.

Hispania Sacra, LIX

119, enero-junio 2007, 85-140, ISSN: 0018-215-X 
Pero la mayor parte de los clérigos que se unieron al bando de los rebeldes siguen resultando para nosotros individuos anónimos, como es el caso, por ejemplo, de todos aquellos que, según los cronistas, reclutó en la Tierra de Campos el obispo Acuña, y que le acompañaron en sus campañas de saqueo por esta comarca, fuertemente armados, a pesar de su condición clerical.

\section{Actitud hacia las Comunidades de los miembros del alto clero}

El sector del clero menos inclinado a apoyar la revuelta comunera fue, sin duda, el constituido por los obispos, entre los cuales hubo, por el contrario, varios que se contaron entre los principales dirigentes realistas, empezando por el gobernador designado por Carlos a raíz de abandonar Castilla en mayo de 1520, el cardenal Adriano de Utrecht, que ocupaba la sede de Tortosa, en Cataluña, y continuando con figuras tan relevantes como las de Guillermo de Croy, arzobispo de Toledo, Pedro Ruiz de la Mota, obispo de Badajoz y luego de Palencia, Juan Rodríguez de Fonseca, obispo de Burgos, o Antonio de Rojas, arzobispo de Granada y presidente del Consejo Real. La única excepción importante vino representada por el obispo de Zamora, Antonio de Acuña, que fue uno de los principales dirigentes de la revuelta, y el único miembro del estamento eclesiástico que fue ejecutado en castigo por su participación en la misma ${ }^{152}$.

La actuación de este belicoso obispo durante los años 1520 y 1521 resulta desde muchos puntos de vista paradójica, y ha dado lugar a muy diversas interpretaciones a la hora de determinar sus auténticas motivaciones, que no entraremos a detallar aquí. En cualquier caso, al margen de cuáles fuesen sus motivaciones, su figura se alza solitaria y enigmática en el panorama de estos años, pues ningún otro obispo o figura destacada de la jerarquía eclesiástica castellana se atrevió entonces a adoptar una actitud de tan abierto desafío a la autoridad del rey como la suya. Hubo ciertamente uno, Diego Ramírez de Villaescusa, obispo sucesivamente de Astorga, Málaga y Cuenca, además de presidente de la Chancillería de Valladolid, que llegó a ser acusado por haber manifestado ciertas simpatías hacia la causa comunera. Pero lo cierto es que nunca llegó a prestar abiertamente apoyo a los rebeldes, y se limitó a trabajar por conseguir una solución negociada al conflicto, llegando a ofrecerse el mismo como intermediario $^{153}$. Y, por lo que respecta a otro obispo que también es puesto en relación con los comuneros por Edward Cooper, el de Lugo, Don Pedro Ribera, lo cierto

152 Vid. Alfonso María GUILARTE, op. cit.

153 Félix G. Olmedo, Diego Ramírez Villaescusa (1459-1537). Fundador del colegio de Cuenca y autor de los cuatro diálogos sobre la muerte del príncipe Don Juan, Madrid, Editora Nacional, 1944. 
es que dicha relación se reduce prácticamente al hecho de que era tío de Catalina Ribera, viuda del ajusticiado licenciado Rincón, uno de los principales exceptuados de Medina del Campo ${ }^{154}$. Pero esto dice muy poco respecto a cuál fue su posición personal ante el conflicto.

154 Vid. Edward CoOPER, «La Iglesia y los comuneros...», pp. 280-1.

Hispania Sacra, LIX

119, enero-junio 2007, 85-140, ISSN: 0018-215-X 